\title{
Pituitary cell phenotypes involve cell-specific Pit-1 mRNA translation and synergistic interactions with other classes of transcription factors
}

\author{
Donna M. Simmons, ${ }^{2,4}$ Jeffrey W. Voss, ${ }^{1}$ Holly A. Ingraham, ${ }^{1,2}$ Jeffrey M. Holloway, ${ }^{1,3}$ Ronald S. \\ Broide, ${ }^{4}$ Michael G. Rosenfeld, ${ }^{1,2}$ and Larry W. Swanson ${ }^{2,4}$ \\ ${ }^{1}$ Eukaryotic Regulatory Biology Program, Center for Molecular Genetics, ${ }^{2}$ Howard Hughes Medical Institute, Department of \\ Medicine, and ${ }^{3}$ Department of Chemistry, University of California at San Diego, School of Medicine, La Jolla, California \\ 92093-0613 USA; ${ }^{4}$ The Salk Institute, Neural Systems Laboratory, La Jolla, California 92037 USA
}

Development of the anterior pituitary gland involves proliferation and differentiation of ectodermal cells in Rathke's pouch to generate five distinct cell types that are defined by the trophic hormones they produce. A detailed ontogenetic analysis of specific gene expression has revealed novel aspects of organogenesis in this model system. The expression of transcripts encoding the $\alpha$-subunit common to three pituitary glycoprotein hormones in the single layer of somatic ectoderm on embryonic day 11 establishes that primordial pituitary cell commitment occurs prior to formation of a definitive Rathke's pouch. Activation of Pit-1 gene expression occurs as an organ-specific event, with Pit-1 transcripts initially detected in anterior pituitary cells on embryonic day 15. Levels of Pit-1 protein closely parallel those of Pit-1 transcripts without a significant lag. Unexpectedly, Pit-1 transcripts remain highly expressed in all five cell types of the mature pituitary gland, but the Pit-1 protein is detected in only three cell types-lactotrophs, somatotrophs, and thyrotrophs and not in gonadotrophs or corticotrophs. The presence of Pit-1 protein in thyrotrophs suggests that combinatorial actions of specific activating and restricting factors act to confine prolactin and growth hormone gene expression to lactotrophs and somatotrophs, respectively. A linkage between the initial appearance of Pit-1 protein and the surprising coactivation of prolactin and growth hormone gene expression is consistent with the model that Pit-1 is responsible for the initial transcriptional activation of both genes. The estrogen receptor, which has been reported to be activated in a stereotypic fashion subsequent to the appearance of Pit-1, appears to be capable, in part, of mediating the progressive increase in prolactin gene expression characteristic of the mature lactotroph phenotype. This is a consequence of synergistic transcriptional effects with Pit-1, on the basis of binding of the estrogen receptor to a response element in the prolactin gene distal enhancer. These data imply that both transcriptional and post-transcriptional regulation of Pit-1 gene expression and combinatorial actions with other classes of transcription factors activated in distinct temporal patterns, are required for the mature physiological patterns of gene expression that define distinct cell types within the anterior pituitary gland.

[Key Words: Transcription factors; Pit-1; pituitary; Rathke's pouch; prolactin; growth hormone]

Received January 30, 1990; revised version accepted February 27, 1990.

The analysis of developmental events resulting in organogenesis and the appearance of distinct cellular phenotypes has been more difficult in vertebrates than in Drosophila and Caenorhabditis elegans, where analysis of mutants has suggested complex networks of interactions between developmental factors that activate the expression of homeotic genes specifying organ development and cell phenotypes (Sternberg and Horvitz 1984; Gehring 1987). Recently, insights into the molecular basis of cell phenotypes in mammals has been approached successfully by characterizing the cis-active elements that are necessary for tissue-specific expression, and by the subsequent isolation of tissue-specific tran- scription factors that bind to these elements (e.g., Walker et al. 1983; Nelson et al. 1986; Staudt et al. 1986; Bodner and Karin 1987; Courtois et al. 1987; Hammer et al. 1987a,b; Costa et al. 1988; Jones et al. 1988; Nelson et al. 1988; Singh et al. 1988).

The process by which distinct cell types develop within an organ is particularly amenable to investigation by analysis of anterior pituitary ontogeny. While the posterior lobe is derived from the neuroectoderm and contains the axon terminals of hypothalamic magnocellular neurosecretory neurons, the anterior and intermediate lobes are generally thought to arise from a placode in the somatic ectoderm. Although there are no 
phenotypic markers for cells in this placodal region, a definitive Rathke's pouch is formed within it by embryonic day 12 (e12) in the rat (Schwind 1928). Immunohistochemical studies indicate that five phenotypically distinct cell types appear during ontogeny in a stereotypical order (Chatalain et al. 1979; Watanabe and Daikoku 1979; Oliver et al. 1980; Gash et al. 1982; Hoeffler et al. 1985; Lugo et al. 1989|. These cell types include, in apparent order of initial appearance: corticotrophs producing pro-opiomelanocortin (POMC), thyrotrophs producing the $\beta$-subunit of thyroid-stimulating hormone $(\beta T S H)$, gonadotrophs producing the $\beta$-subunits of follicle-stimulating and luteinizing hormones $(\beta F S H$ and $\beta L H)$, somatotrophs producing growth hormone $(\mathrm{GH})$, and lactotrophs producing prolactin (PRL). To date, there is no evidence that surrounding mesodermal or neural tissues influence this pattern of development, although both appear to control the rate of cell proliferation within the anterior pituitary (Frémont and Ferrand 1979a,b; Begeot et al. 1982; Daikoku et al. 1982; Watanabe 1982; Schechter et al. 1985).

In adults, expression of the structurally related $\mathrm{GH}$ and PRL genes is limited to the anterior pituitary and to distinct cell types within it. However, the transient coexpression of these endocrine genes within putative precursor cells prior to the appearance of mature lactotrophs, as well as in a small population of mature anterior pituitary cells (Chatelain et al. 1979; Watanabe and Daikoku 1979; Hoeffler et al. 1985), raises the possibility that the PRL and GH genes are developmentally regulated by related factors. Data from gene-directed $a b$ lation studies in transgenic mice are consistent with the notion that at least most lactotrophs are derived from a presomatotroph lineage (Behringer et al. 1988; Borrelli et al. 1989). The cell-specific expression of high levels of the rat PRL and GH genes depends on a series of cell-specific cis-active elements (Nelson et al. 1986, 1988; Bodner and Karin 1987; Cao et al. 1987; GutierrezHartman et al. 1987; Lufkin and Bancroft 1987; West et al. 1987; Ye and Samuels 1987).

The characterization and purification of a factor that binds to particular cell-specific cis-active elements in the rat PRL and GH genes (Ingraham et al. 1988; Mangalam et al. 1989) permitted the cloning of a pituitaryspecific factor, referred to as Pit-1 (Bodner et al. 1988; Ingraham et al. 1988). The coding sequence of Pit-1 predicted a 291-amino-acid protein that was found to be a member of a novel family of transcription factors containing a highly conserved domain, referred to as the POU domain (Herr et al. 1988), and including the octamer-binding proteins Oct-1 and Oct-2 (Clerc et al. 1988; Ko et al. 1988; Müller et al. 1988; Scheidereit et al. 1988; Sturm et al. 1988), the C. elegans developmental regulator unc-86 (Finney et al. 1988), and multiple related proteins expressed in mammalian and Drosophila neurons (He et al. 1989; M. Treacy, X. He, C.S. Zucker, and M.G. Rosenfeld, in prep.). Expression of Pit-1 in heterologous cell types is capable of activating both rat PRL and GH promoters, even when Pit-l is expressed at levels much lower than those in pituitary cells (In- graham et al. 1988, 1990; Mangalam et al. 1989; Fox et al. 1990). The availability of Pit-1 cDNA and protein permits a detailed analysis of the potential role of Pit-1 in gene activation and the development of distinct pituitary cell types.

Here, we report that the pituitary cell type arises in a spatially and temporally specific fashion. Expression of one transcript ( $\alpha$-glycoprotein subunit, $\alpha$-GSU) occurring prior to formation of Rathke's pouch defines the onset of pituitary organogenesis. The Pit-1 gene transcript is initially detected on e 15 in most cells of the anterior pituitary, with Pit-1 protein initially appearing at very low levels at essentially the same time, preceding PRL and GH gene activation. Pit- $I$ is suggested to be required for the initial activation of both of these transcription units, each of which requires the actions of other factors to achieve full physiological levels of expression. In the case of the PRL gene, the progressive increase in estrogen receptor gene expression after birth may account, at least in part, for the progressive postnatal increase in PRL gene expression characteristic of phenotypically mature lactotrophs and is based on synergistic interactions between estrogen receptor and Pit-1 to activate the PRL distal enhancer. Pit-1 gene transcripts are expressed in all five phenotypically distinct pituitary cell types, although Pit-1 protein is detected only in the nuclei of thyrotrophs, lactotrophs, and somatotrophs. The expression of Pit-1 protein in thyrotrophs, in concert with previous analyses of transgenic mice (Crenshaw et al. 1989), suggests that specific restrictive mechanisms prevent the expression of GH and PRL genes in this cell type. Thus, transcriptional and posttranscriptional regulation of Pit-1, and the temporal lag in maximal expression of the estrogen receptor, could account for the ontogeny and physiological levels of PRL gene expression characteristic of the lactotroph cell type.

\section{Results}

Ontogeny of trophic hormone gene expression defines the onset of hypophyseal organogenesis

To clarify the molecular events that dictate pituitary development and ultimately culminate in the appearance of distinct somatotroph and lactotroph cell types, initial studies were directed at defining the ontogeny of expression of transcripts for each hormone in the anterior pituitary using $\left.{ }^{35} \mathrm{~S}\right] \mathrm{cRNA}$ probes specific for the hormones and for Pit-1, as summarized in Table 1. On el1, at a time just after closure of the anterior neuropore, probes against the mouse and rat $\alpha$-glycoprotein subunit, which is common to $\beta \mathrm{TSH}, \beta \mathrm{LH}$, and $\beta F S H$, exhibited dense, restricted hybridization to an oval patch of the simple columnar epithelium in the ectoderm beneath the neural tube with a clear posterior-to-anterior gradient of hybridization (Fig. 1). This unexpected expression of the $\alpha$-subunit transcript provides the first known phenotypic marker for cells throughout the hypophyseal placode, which contains the presumptive anterior and in- 
Table 1. Summary of ontogeny of Pit-1 and hormone mRNA expression in rat anterior pituitary as determined by in situ hybridization

\begin{tabular}{|c|c|c|c|c|c|c|c|c|c|c|c|c|c|}
\hline & E10.5 & E11.5 & E12.5 & E13.5 & E14.5 & E15.5 & E16.5 & E17.5 & E18.5 & E19.5 & P0.5 & P2.5 & P10 \\
\hline$\alpha G S u$ & - & +++ & +++ & +++ & +++ & +++ & +++ & +++ & +++ & +++ & +++ & +++ & \\
\hline POMC & - & - & - & $\pm^{\mathrm{a}}$ & + & ++ & +++ & +++ & +++ & +++ & +++ & +++ & \\
\hline$\beta T S H$ & - & - & - & - & + & + & ++ & +++ & +++ & +++ & +++ & +++ & \\
\hline$\beta L H$ & - & - & - & - & - & - & + & + & + & ++ & +++ & +++ & \\
\hline$\beta F S H$ & - & - & - & - & - & - & - & + & + & ++ & +++ & +++ & \\
\hline $\mathrm{GH}$ & - & - & - & - & - & - & - & \pm & +++ & +++ & +++ & +++ & +++ \\
\hline PRL & - & - & - & - & - & - & - & + & + & + & + & ++ & $++t$ \\
\hline Pit-1 & - & - & - & - & - & \pm & +++ & +++ & +++ & +++ & +++ & +++ & +++ \\
\hline
\end{tabular}

$(-\mid$ Not detected; $( \pm \mid$ low levels in some embryos; $|+|$ low levels; $1++\mid$ moderate levels; $|+++|$ high levels.

aBased on our results and those of Lugo et al. (1989).

termediate lobes and is embedded within ectoderm destined for the roof of the mouth. By e12, the $\alpha$-subunit expression is restricted to the definitive Rathke's pouch and by el 3 it is even further restricted to the ventral part of the anterior half of the pouch, in the region where the definitive anterior lobe first appears just at this time (Fig. 1). Further restriction ultimately confines $\alpha$-subunit transcript expression in the mature pituitary to thyrotrophs and gonadotrophs.

Distinct cell types were first detected in the pituitary on e14, with the expression of POMC and $\beta$ TSH transcripts in a small proportion of the cells in the anterior lobe (Fig. 2), 12-24 hr preceding detectable proteins (Watanabe and Daikoku 1979; Daikoku et al. 1983; Lugo et al. 1989). Interestingly, 2 days earlier, very abundant POMC transcripts were detected in many cells of the adjacent ventromedial hypothalamus (Fig. 2), in the region of the presumptive arcuate nucleus; POMC protein has been noted in the hypothalamus on e12 (Schwartzberg and Nakone 1982; Kachaturian et al. 1983). Surprisingly, these genes exhibited clear spatial patterns of expression. POMC-expressing cells were centered in caudal parts of the anterior lobe, while $\beta$ TSH-expressing cells were segregated in the anterior part of the lobe in the region adjacent to the opening of Rathke's pouch into the roof of the mouth, where the $\alpha$-glycoprotein subunit transcripts were now also localized. Thus, during a restricted period of time around e13-e14, the first differentiated cells in the newly forming anterior lobe are the only regions in the pituitary that express mRNA for POMC, $\beta$ TSH, and $\alpha$-glycoprotein subunit.

Critical events in hypophyseal development occur on e16 when significant blood vessels and accompanying mesoderm first invade the parenchyma of the anterior lobe; the first secretory granules can be observed in some anterior pituitary cells; and the first axon terminals from the hypothalamus reach the neurohemal zone of the median eminence, allowing the potential delivery of hypothalamic trophic hormones (Fink and Smith 1971; Dearden and Holmes 1976; Daikoku et al. 1981). Coincident with these events, we found the initial appearance of Pit-1 transcripts on e15-e16 throughout the caudal four-fifths of the anterior lobe, and at levels comparable to those found in the adult, although Pit-1 transcripts were conspicuously absent in the cluster of thyrotrophs in anterior regions of the gland on e16 (data not shown). There is a dramatic increase in the levels of Pit-1 transcripts between e15 and e16. To confirm that these transcripts represented Pit-1 mRNA, hybridization was performed using either $5^{\prime}$ - or $3^{\prime}$-untranslated region probes, with identical results (Fig. 3A). Because polymerase chain reaction analyses are nonquantitative and, in this type of embryological analysis, may be subject to false positives, RNase protection assays were performed to determine unequivocally the time of initial significant expression of Pit-1 mRNA. These assays confirm that Pit- 1 transcripts were undetectable on e13.5 (at least 3 orders of magnitude less than on e16), but were clearly present in the anterior pituitary by e15.5-e16 (M. Treacy and M.G. Rosenfeld, unpubl.; He et al. 1989).

The initial appearance of Pit-1 protein was investigated by direct assay of Pit-1 protein using Western blot analyses and by antibody-perturbated gel mobility-shift assays (Fig. 3B,C). Protein extracts of isolated anterior pituitary glands from el5 to day 10 after birth (p10) were assayed using highly specific, high-affinity polyclonal antisera against bacterial Pit-1 protein. These antisera are highly specific for Pit-1 protein in GC cells or anterior pituitary gland, and staining is entirely blocked by Pit-1 protein, as determined using a series of bacterially expressed mutant Pit-1 molecules (data not shown). The major epitopes are located in the amino-terminal regions, preceding the POU domain of Pit-1. These assays revealed that the expected $33,31-\mathrm{kD}$ protein doublet of immunoreactive Pit-1 protein was initially detected on e15 (Fig. 3B), and suggested a progressive increase in relative Pit-1 protein concentration through day p10, perhaps, in part, reflecting the proliferation of Pit-1-expressing cells (Fig. 3B). The presence of Pit-1 in the DNA-protein complex, as detected by antibody-perturbated gel mobility-shift, was initially detected on e16-e17 (Fig. 3C), using a Pit-1 binding site from the rat PRL promoter (IP). The ontogeny of Pit-1 protein expression was confirmed in three separate analyses. Furthermore, Pit-1 antisera provided clear immunostaining on e16 (data not shown). These data suggest that there is a minimal, if any, lag between initial expression of Pit-1 mRNA and functional Pit-1 protein during pituitary ontogeny. 

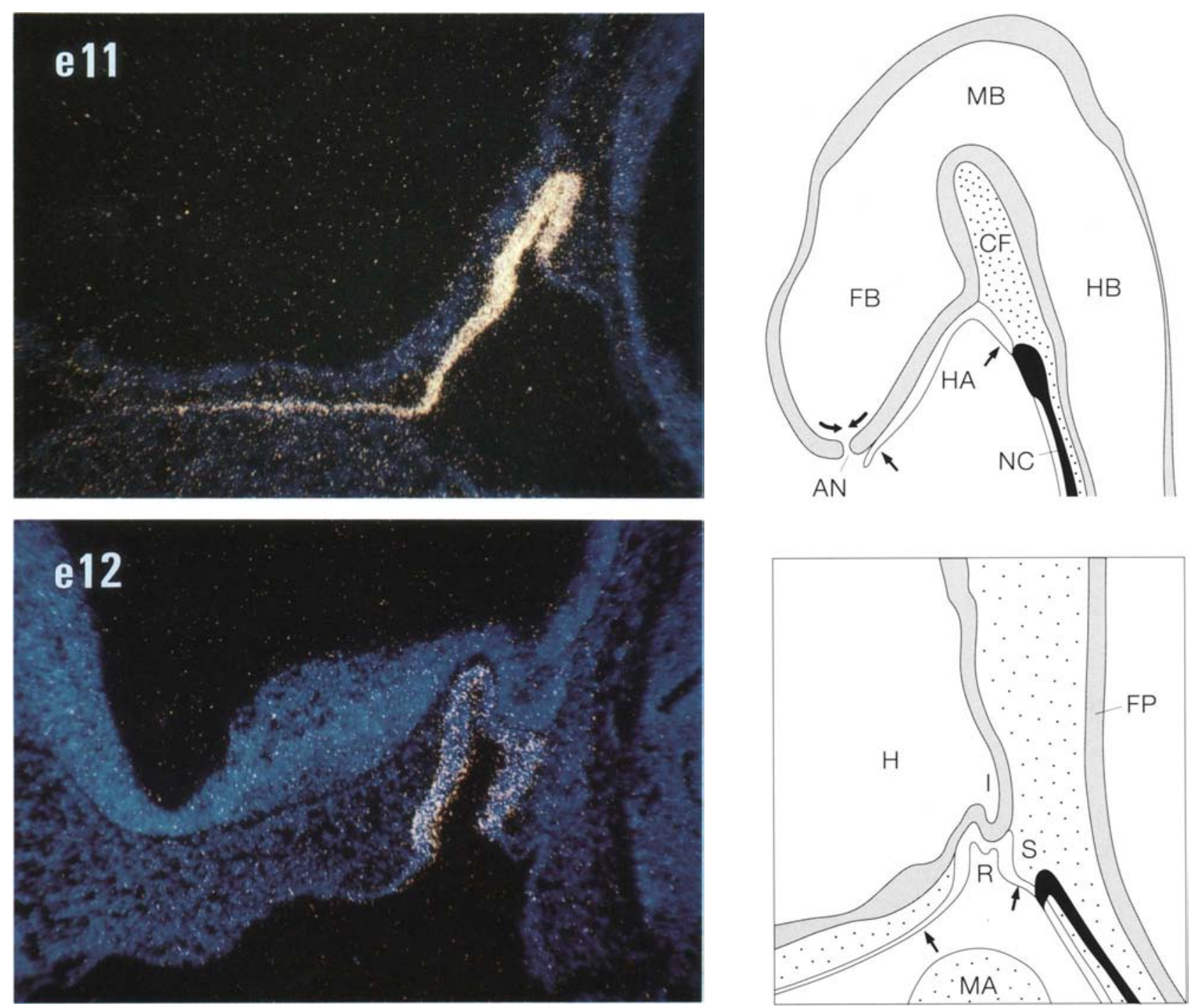

Figure 1. (Continued on facing page.)

The initial appearance of small numbers of cells expressing mRNAs for PRL and, to a lesser extent, GH, was also observed caudally and dorsally on e17. On e18 a much larger number of GH-hybridized cells were found scattered throughout most of the anterior lobe lexcept the rostral tip), whereas the number of PRL-hybridized cells increased only slightly (Fig. 2). Cells expressing PRL and GH were scattered relatively widely throughout the anterior lobe, except in the rostral portion. By this time, cells expressing POMC, $\beta T S H, P R L$, and $\mathrm{GH}$ transcripts were considerably intermixed, except in the rostral tip of the anterior lobe that still contained only $\beta$ TSH-expressing cells (Fig. 2). Therefore, the initial appearance of Pit-1 protein correlates closely with initial expression of the PRL and GH genes, the promoters of which have been shown to be regulated in vitro by Pit-1 (Ingraham et al. 1988, 1990; Mangalam et al. 1989|. Rare cells hybridizing the $\beta$ LH probe were observed in the ventral part of the anterior lobe on e16, with many more cells hybridizing $\beta \mathrm{LH}$ and $\beta \mathrm{FSH}$ probes appearing on e17. The presumptive gonadotrophs $(\beta L H$ and $\beta F S H$ ) were centered ventrally in a strip of tissue that lies about midway between the rostral and caudal poles.

Pit-1 transcripts are expressed in all five pituitary cell types, but detectable Pit-1 protein expression is restricted to thyrotrophs, lactotrophs, and somatotrophs

We have previously reported the detection of putative Pit-1 transcripts by hybridization histochemistry in the neural tube on e10-el1 (He et al. 1989). We confirmed the expression of Pit-1 transcripts in developing neural tube using a probe complementary to the $3^{\prime}$-untranslated region of the Pit-1 transcript, and we determined that Pit-1 transcripts were expressed in the neural tube but were not detectable in the somatic ectoderm of the nascent hypophyseal placode (e11, R, Fig. 3A). RNase protection experiments (He et al. 1989) were repeated to 

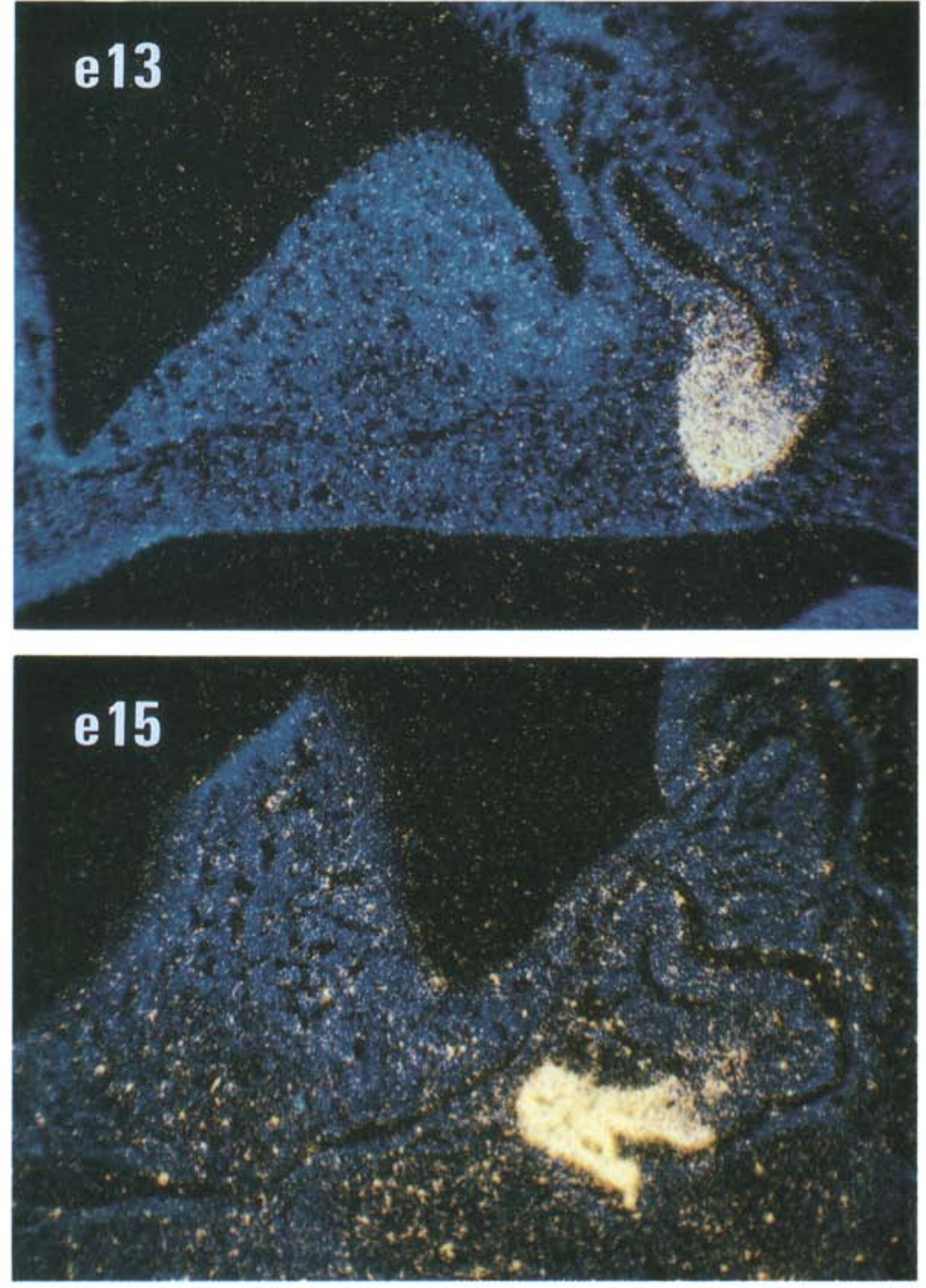
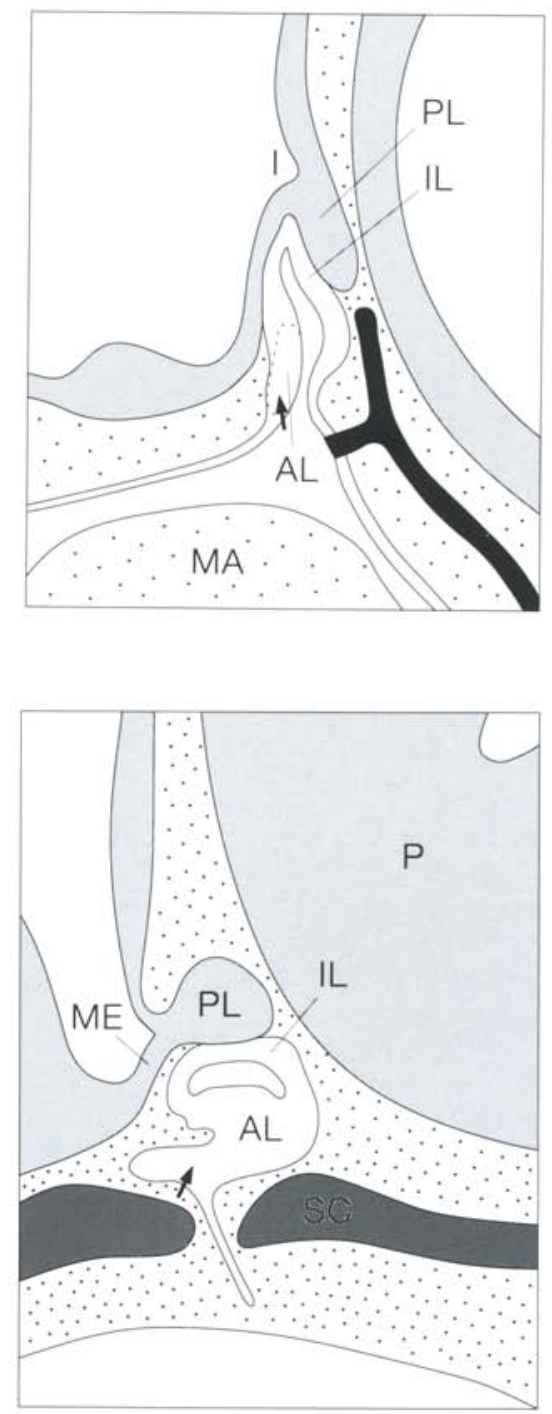

Figure 1. Identification of a marker for initial pituitary development. The photomicrographs at left illustrate the sequential restriction of $\alpha$-glycoprotein subunit transcripts during early developmental stages of the pituitary. The adjacent drawings show the ontogeny of tissues in and around the pituitary, and are modified from Schwind (1928). On embryonic day 11 (ell), transcripts are expressed in an oval region of cells that presumably defines the hypophyseal placode, a part of the original anterolateral ridge ectoderm that lies between the hypothalamus and oropharyngeal membrane and also gives rise to ectoderm in the roof of the mouth and nose, as well as in the olfactory placode (see Adelmann 1925; Couly and Le Douarin 1985; Jacobson and Sater 1988); note that hybridization is most dense posteriorly. On el2, transcripts are restricted to the definitive Rathke's pouch, which gives rise to both the anterior (anterior wall) and intermediate (posterior wall) lobes, whereas, on el3 and e15 expression is further restricted to the incipient anterior lobe. All figures are in the midsagittal plane, with anterior to left and dorsal to top; in situ hybridization with probe to mouse $\alpha$-glycoprotein subunit. Bisbenzimide counterstain; magnification, $80 \times$. Abbreviations: (AL) Anterior lobe; (AN) anterior neuropore; (CF) cranial flexure; (FB) forebrain; (FP) floor plate of pontine neural tube; $(\mathrm{H})$ hypothalamus; (HB) hindbrain; (I) infundibulum; (IL) intermediate lobe; (MA) maxillary process; (MB) midbrain; $(\mathrm{ME})$ median eminence; (NC) notochord; $(\mathrm{P})$ pons; $(\mathrm{PL})$ posterior lobe; (R) Rathke's pouch; (S) Seessle's pouch; (SC) sphenoid cartilage.

confirm that transcripts derived from the Pit-1 gene disappeared from the neural tube following transient expression of Pit-1 on e11, and the absence of detectable transcripts on el3, before reappearing on e15-e18 (data not shown). Each RNA tested was confirmed to be intact, and the identical preparations were positive for Brn-2 POU domain gene expression (He et al. 1989), confirming that the RNA and CDNA were representational. Western blot analyses of head extracts from e11 embryos also showed no detectable Pit-1 protein (Fig. 3B; data not shown). These data confirm our previous observations that the Pit-1 gene exhibits a biphasic pattern of developmental expression (He et al. 1989).

On the basis of evidence that the Pit-1 gene was initially expressed in most cells of the anterior pituitary, the expression of Pit-1 transcripts and Pit-1 protein was examined in each of the five classical cell types in the anterior pituitary gland of mature animals. Transcripts 


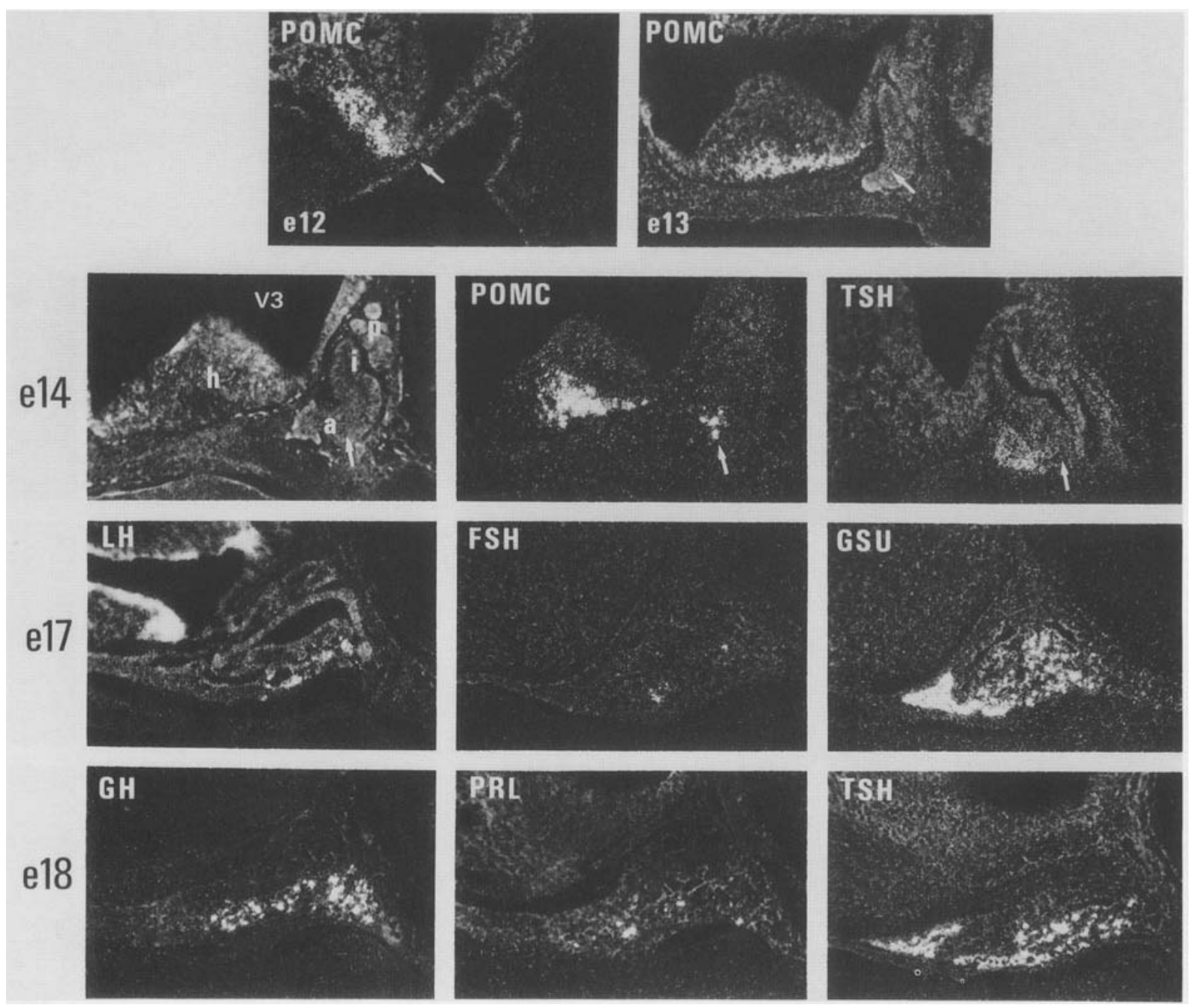

Figure 2. Activation of trophic hormone gene expression in the developing anterior pituitary gland. Photomicrographs show in situ hybridization of the developing hypothalamic-pituitary axis. On ell and el2, POMC transcripts are localized to cells in the mantle layer of the basomedial hypothalamus, just opposite (arrows) the zone of Rathke's pouch where POMC is later expressed in the incipient anterior lobe (see e14). Note that on e14, POMC (arrows) and $\beta$ TSH (TSH) are expressed in separate caudal and rostral compartments of the anterior lobe (the figure to left shows the bisbenzimide counterstain of the POMC-hybridized section). (a) Anterior lobe; (h) hypothalamus; (i) intermediate lobe; (p) posterior lobe; (V3) third ventricle. On e17, cells expressing $\beta \mathrm{LH}$ (LH) and $\beta F S H(F S H)$ transcripts are evident ventrally in the anterior lobe; $\alpha$-glycoprotein subunit transcripts are still very abundant in the anterior tip of the anterior lobe, but many hybridized cells are now also evident more posteriorly. On e18 many GH-hybridized cells, and a few PRL-hybridized cells, are clear in the posterior four-fifths of the lobe. Same orientation as Fig. 1. Dark-field illumination; magnification, $60 \times$.

hybridizing to Pit-l cDNA probes were observed in all five cell types, including gonadotrophs and corticotrophs (Fig. 4). To ascertain the specificity of this signal, probes from the $5^{\prime}$ end, encompassing the amino terminus of the protein, and from the $3^{\prime}$-untranslated region, were used independently. In each case, gonadotrophs and corticotrophs exhibited high levels of hybridization. The hybridization signal was consistently higher in LH-containing cells than in somatotrophs, lactotrophs, or thyrotrophs (Fig. 4; Table 2). In contrast, when examined for Pit-1 protein using immunohistochemical co-localization techniques, virtually no corticotrophs and $<1 \%$ of the gonadotrophs contained immunoreactive Pit-1 protein (Fig. 5; Table 2). The rare reactive gonadotrophs might represent the small number of cells recently reported to synthesize both TSH and LH or FSH (Childs et al. 1989). Primer-extension products were observed utilizing pituitary tissue from untreated or estrogen-treated rats or the PRL, GH-producing GC pituitary cell line RNA, suggesting that all pituitary transcripts were the products of a single transcription unit (data not shown). As is usual for this analysis, several prominent, prematurely terminated products were shorter than the predicted 320-nucleotide full-length transcripts (R. Chen, H.A. Ingraham, M.N. Treacy, V.R. Albert, and M.G. Rosenfeld, in prep.). On the basis of their size, all of these shorter products would be translated to yield Pit-1 protein. Finally, both RNase and polymerase chain reaction 


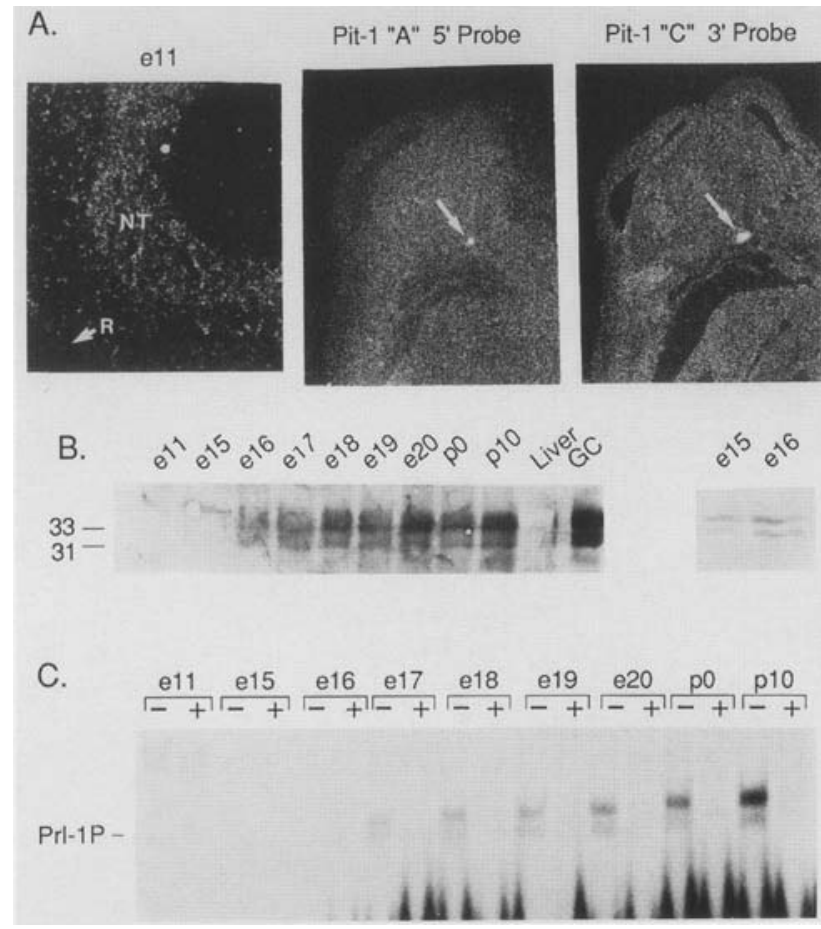

Figure 3. Ontogeny of Pit-1 mRNA and Pit-1 protein expression. (A) Pit-1 transcripts are expressed in neural tube and developing anterior pituitary. Using Pit-1 probes directed to the $3^{\prime}$-untranslated region $\left(3^{\prime}\right)$ or $5^{\prime}$ sequence preceding the POUdomain binding region $\left(5^{\prime}\right)$, hybridization was observed on ell in neural tube (NT) but not Rathke's pouch (R). Detectable hybridization in the pituitary (arrow) was initially observed on el5.5-e16, with similar results using 5 '- or 3 '-specific probes. (B) Immunological detection of blotted Pit-1 protein following quantitation of SDS polyacrylamide gels. Extracts were prepared from total head (ell) or isolated pituitary glands (el5p10) or GC pituitary cells; $30 \mu \mathrm{g}$ of protein was fractionated, transferred to nitrocellulose, reacted with Pit-1 antisera, and developed using a horseradish peroxidase colorimetric assay and a biotin/avidin amplification system (see Experimental methods|. A second experiment, shown at right, indicated the presence of low levels of Pit-1 protein on e15. (C) Antibody-perturbated gel mobility-shift analyses of Pit-1 activity. A ${ }^{32} \mathrm{P}-\mathrm{la}$ beled PRL 1P site (Ingraham et al. 1988) was used as a probe with $0.5 \mu \mathrm{g}$ of soluble pituitary cell extract, as described in Experimental methods. Preimmune $(-)$ or immune $(+) \alpha$ Pit- 1 sera were added to a final dilution of $1: 1000$ prior to electrophoresis. Under these conditions, addition of Pit-1 antiserum abolishes formation of the indicated PRL-1P protein complex.

analysis failed to detect any alternative RNA species within the coding region. As gonadotrophs and corticotrophs represent $\sim 10 \%$ of pituitary cells, a variant transcript could potentially escape detection by this analysis. In addition to the expression of Pit-l protein in $78 \%$ and $80 \%$ of mature somatotrophs and lactotrophs, respectively, we found the protein expressed in a comparable percentage of thyrotrophs (Fig. 5; Table 2). A detailed quantitation revealed that most $(\sim 80 \%)$, but not all, somatotrophs, lactotrophs, and thyrotrophs contained detectable Pit-1 protein (Table 2). These data were consistent with previous observations /Crenshaw et al. 1989|, suggesting that restrictive mechanisms, as well as Pit-1-dependent gene activation, were required for cell-specific patterns of growth hormone and prolactin gene expression.

Combinatorial actions of distinct transcription factors The temporal association of the initial expression of the Pit-1, PRL, and GH genes is consistent with the possibility that Pit-1 exerts a critical developmental function in the initial activation of these two transcription units. This observation presents a conundrum because, ultimately, these two genes are expressed in distinct cell types. A clue to the mechanisms of cell-specific expression has been provided by defining the temporal patterns of maximal gene expression of these two trophic hormones. While GH gene expression was maximal by e19-e20, the PRL gene exhibited a gradual, marked (10to 50-fold) increase in expression between the initial appearance at e17 and full expression $\sim 10-15$ days after birth. Because synergistic interactions between the proximal promoter and the distal enhancer regions of the PRL gene were necessary to achieve high levels of expression in vivo as established in transgenic expression in mice, and on the basis of analysis of specific interactions in the distal enhancer in GC pituitary cells (Nelson et al. 1986, 1988; Crenshaw et al. 1989), it became important to determine whether Pit-1 alone was capable of mediating these synergistic interactions between the proximal and distal regulatory regions of the PRL gene. We and others have established that purified or bacterially expressed Pit-1 protein binds effectively to elements in both the rat PRL and GH promoters and can activate transcription of both promoters in cell culture models (Ingraham et al. 1988; Mangalam et al. 1989; Fox et al. 1990; Larkin et al. 1990; D. Sharp, pers. comm.). Permanent HeLa cell transfectants (Pit- $1^{+}$HeLa) that express Pit-1 protein at levels 10-fold lower than those in pituitary cells actually activate PRL fusion genes under control of the rat PRL promoter even more effectively than those under control of the GH promoter (Mangalam et al. 1989).

Several experiments were performed to begin to determine the molecular basis for the ontogeny of PRL gene activation. The efficacy of transcription of fusion genes containing the full rat PRL promoter or the distal enhancer or both regions was compared to the rat $\mathrm{GH}$ promoter in pituitary (GC) cells or in Pit- $1^{+}$HeLa cells $\left(\mathrm{HeLa}-\mathrm{Pit}-1^{+}\right)$as quantitated by immunotitration (data not shown). As shown in Figure 6A, while both the PRL promoter element and the distal enhancers can independently enhance fusion gene expression, they exert marked synergistic effects in GC pituitary cells, in concert with previously published results (Nelson et al. 1986, 1988; Crenshaw et al. 1989). In contrast, PRL promoter elements, but not the distal enhancer, were highly stimulated in Pit-1 ${ }^{+}$HeLa cells, and no Pit-1-dependent synergism between the proximal promoter and 


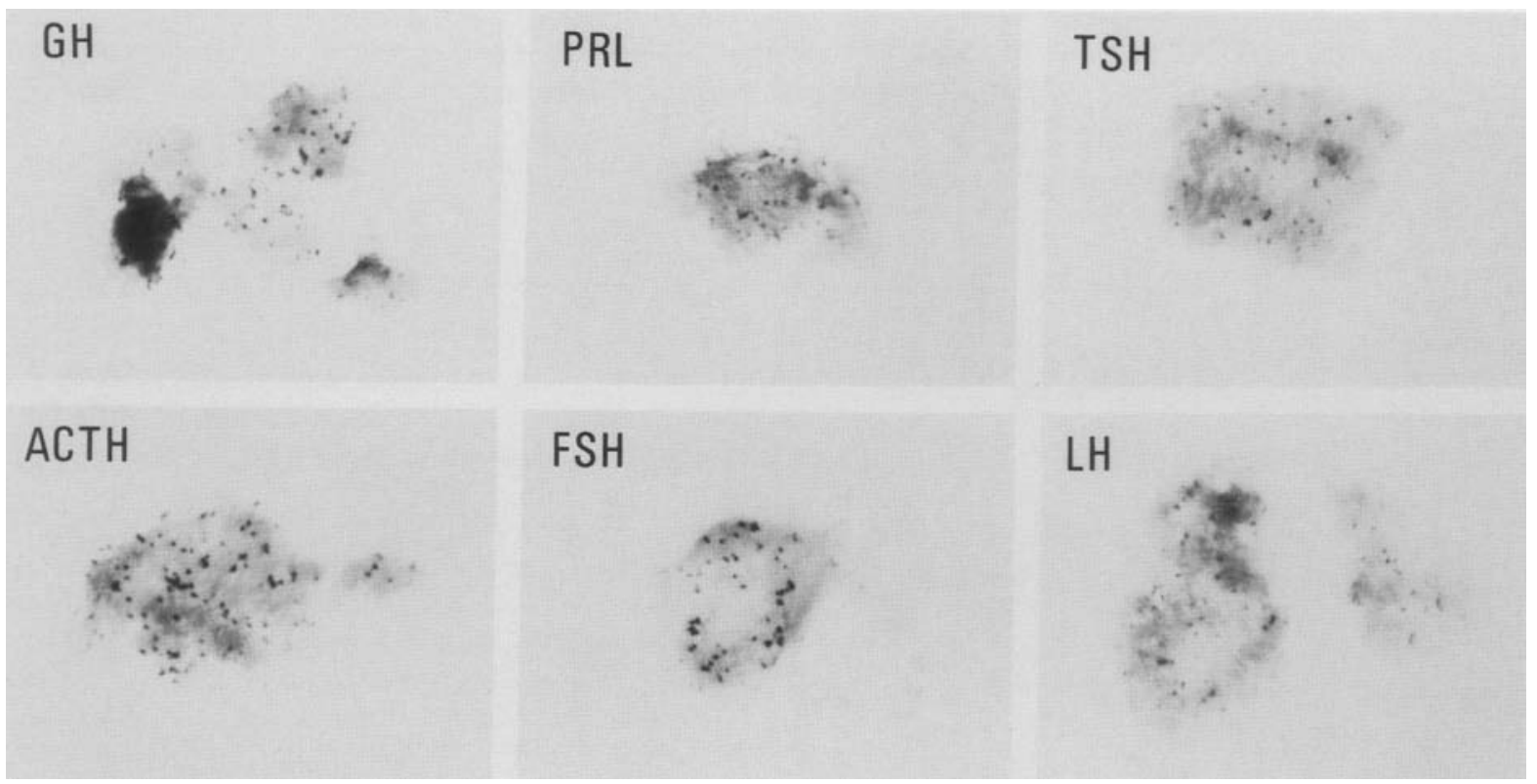

Figure 4. Expression of Pit-1 mRNA in all five anterior pituitary cell types. Immunohistochemistry with rabbit antisera to the various trophic hormones or their specific subunits was carried out on dispersed rat anterior pituitary cells cultured for 30 min. This was followed by in situ hybridization (black silver grains) with a $3^{\prime}$-untranslated-directed ${ }^{35} \mathrm{~S}$-labeled probe. Similar results were obtained with a probe complementary to the $5^{\prime}$ region, on cultures maintained for $60 \mathrm{~min}$ or 3 days, as well as in 10- $\mu \mathrm{m}$-thick sections of the adult pituitary.

the distal enhancer element was observed, suggesting that Pit-1, in the context of HeLa cells, was incapable of stimulating the distal enhancer (Fig. 6B). Interestingly, the proximal promoter is very well expressed in these cells. In transient cotransfection analysis, Pit-1 was invariably ineffective in stimulating the distal enhancer element, while always very effective in activating fusion genes under control of the proximal promoter. The Pit-1-dependent stimulation of the PRL proximal promoter was greater than that observed for the rat GH promoter, while reciprocal data were consistently observed in GC cells (Fig. 6A). Thus, factors in addition to Pit-1 are required for full PRL gene activation and apparently must appear developmentally after birth. In contrast, the factors in addition to Pit- 1 that are required for full physiological levels of GH gene expression are apparently expressed by e18.
One candidate for a transcriptional coregulator of PRL gene expression appearing after birth is the estrogen receptor, because estrogen binding has been suggested to increase $>10$-fold in the pituitary between birth and day 20 (Slabaugh et al. 1982) and because a well-characterized estrogen response element is localized in the distal PRL gene enhancer (Maurer and Notides 1987; Waterman et al. 1988). The role of the estrogen receptor in the activation of the distal enhancer of the rat PRL gene was explored by cotransfecting plasmids expressing Pit-1 and estrogen receptor with rat fusion genes under the control of PRL 5'-flanking information into heterologous cells $(\mathrm{CV}-1)$ that do not express endogenous estrogen receptors (Glass et al. 1988) As shown in Figure 6C, Pit-1 expression was required for significant basal expression, whereas expression of estrogen receptors alone produced no detectable or minimal transcriptional

Table 2. Summary of Pit-1 expression in cell types of mature rat anterior pituitary

\begin{tabular}{|c|c|c|c|}
\hline \multirow[b]{2}{*}{ Cell types } & \multicolumn{2}{|c|}{$\begin{array}{l}\text { Pit-1 transcripts } \\
\end{array}$} & \multirow{2}{*}{$\frac{\text { Pit- } 1 \text { protein }}{\text { percent cells positive }^{c}}$} \\
\hline & percent cells positive ${ }^{a}$ & levels $^{\mathrm{b}}$ & \\
\hline Somatotrophs (GH) & 100 & $22 \pm 1$ & 78 \\
\hline Lactotrophs (PRL) & 100 & $16 \pm 1$ & 80 \\
\hline Thyrotrophs ( $\beta \mathrm{TSH})$ & 42 & $11 \pm 2$ & 80 \\
\hline Corticotrophs (ACTH $)$ & 100 & $20 \pm 1$ & 0 \\
\hline \multicolumn{4}{|l|}{ Gonadotrophs } \\
\hline$(\beta \mathrm{LH})$ & 92 & $32 \pm 4$ & 1 \\
\hline ( $\beta$ FSH) & 34 & $20 \pm 5$ & 0.5 \\
\hline
\end{tabular}

aPercent cells with $>3 \times$ background (measured over fibroblasts).

bMean ( \pm SEM) number of silver grains/cell (cells $>3 \times$ background).

${ }^{c} n=400$ for each hormone or subunit. 
HORMONES
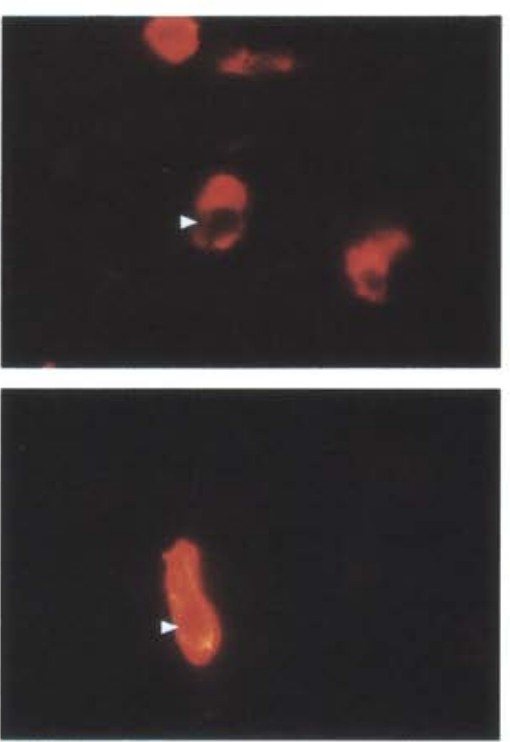

TSH

ACTH
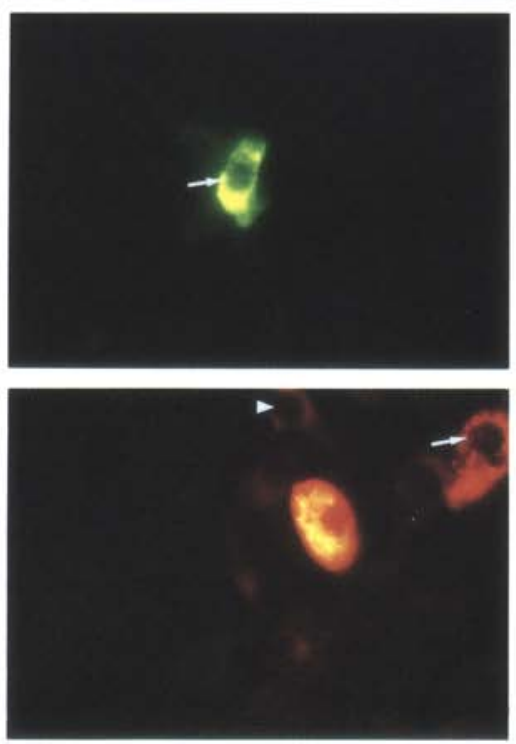

PIT-1
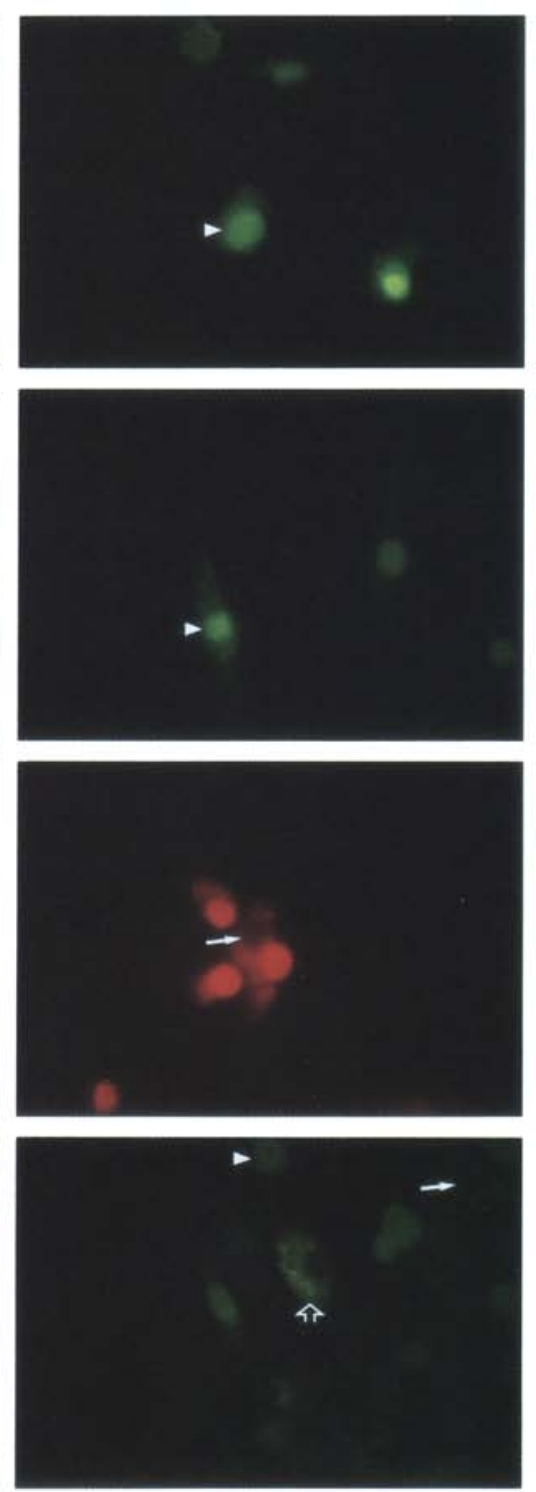

NUCLEI
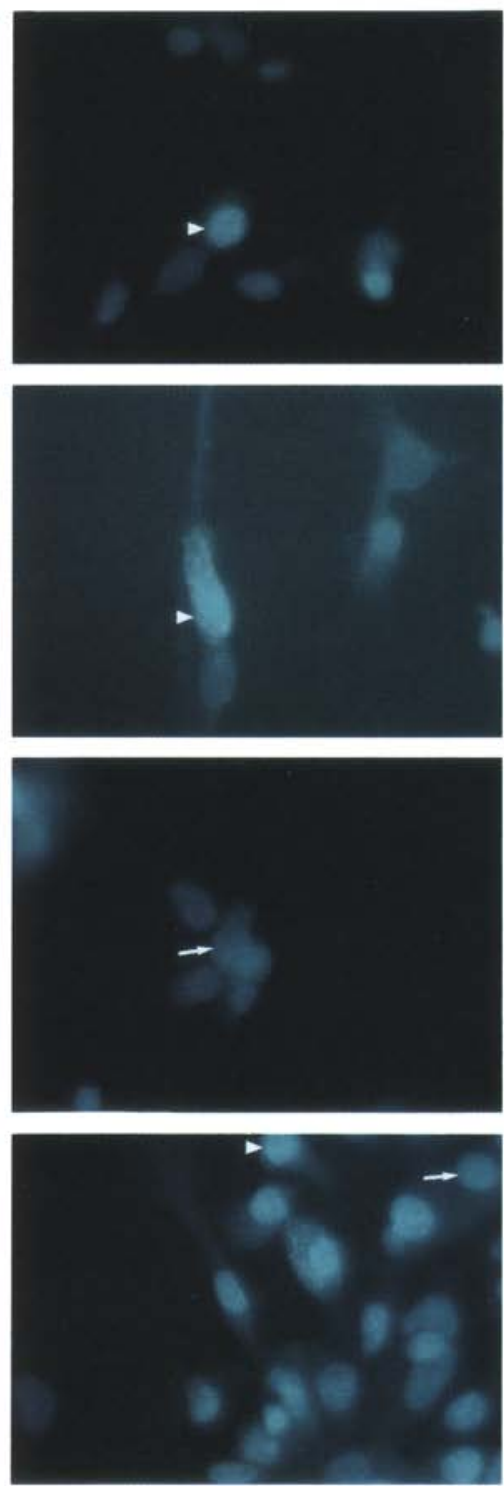

Figure 5. Pit-1 protein is detected in three of the five pituitary cell types. Pit-1 protein is abundant in the nuclei of most somatotrophs $(\mathrm{GH})$ and thyrotrophs (TSH), but is rare or absent in the nuclei of gonadotrophs (LH) and corticotrophs (ACTH). A rabbit antiserum to bacterial Pit-1 was localized with secondary antisera conjugated to fluorescein (GH, TSH, LH) or rhodamine (ACTH), while antisera to the hormones or hormone subunits were raised in other species and localized with secondary antisera conjugated to rhodamine $(\mathrm{GH}, \mathrm{TSH}, \mathrm{LH})$ or fluorescein $(\mathrm{ACTH})$. Cultures were counterstained with bisbenzimide (blue, right column) to show all nuclei in the field. Arrowheads show representative cells with cytoplasmic hormone staining and nuclear Pit-1 staining; arrows indicate examples of hormone-stained cells with no detectable Pit-1 nuclear staining. The open arrow in the LH/Pit-1 photograph indicates "bleeding" of the intense LH rhodamine immunofluorescence through the filter system used to detect fluorescein-labeled Pit-1 protein. Magnification, $490 \times$.

effects, either basally or with addition of estrogen to the cell cultures. Cotransfection of both Pit-1 and estrogen receptors stimulated PRL fusion gene expression comparable to Pit-1 alone; however, in the presence of estrogen, a marked, synergistic activation of PRL gene expression (8- to 15-fold) was observed. This effect was apparently dependent on the estrogen-response element in the PRL distal enhancer, because a cluster mutation al- tering six bases in the estrogen regulatory element that eliminated estrogen receptor binding (Adler et al. 1988) entirely abolished this estrogen-dependent response (Fig. 6). Estrogen-dependent effects on PRL gene expression in GC cells are rarely greater than fourfold; this is likely to reflect, in part, the overlapping nature of recognition elements for various steroid family receptors (Evans 1988; Beato 1989; Glass et al. 1989|, many of which are present 
Simmons et al.

in GC cells and may contribute to basal activation by binding to a series of half-sites adjacent to the estrogenresponse element (C.K. Glass, M.G. Rosenfeld et al., unpubl.). However, if one compares estrogen-stimulated expression of the PRL gene with that in the presence of an estrogen antagonist, a 7- to 15-fold effect is noted. These effects are dependent on the distal enhancer estrogen-response element (S. Adler and M.G. Rosenfeld, unpubl.). The absence of other factors in the CV-1 cells may have permitted a more dramatic detection of the

A.

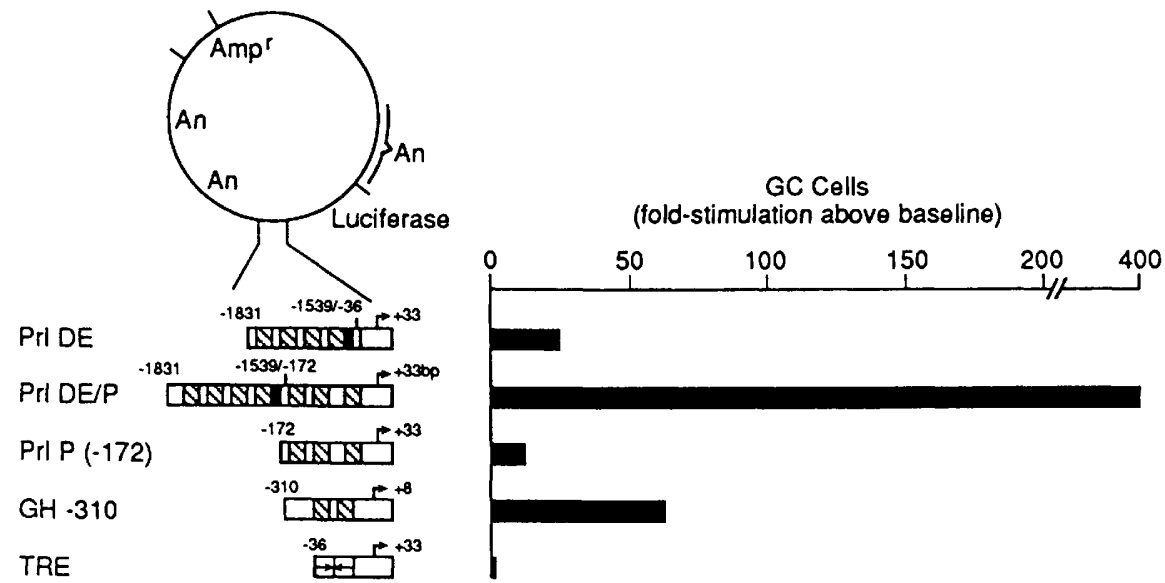

B.

Pit- $1^{+}$. Hela Cells

(fold-stimulation above baseline)

\begin{tabular}{|c|c|}
\hline Prl DE & 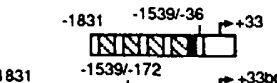 \\
\hline$D E / P^{-1}$ & 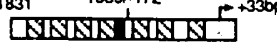 \\
\hline$P(-172)$ & \\
\hline & $\stackrel{-310}{\square}$ \\
\hline & \\
\hline
\end{tabular}

C. Co-transfection with hER Expression Plasmid

$\pm$

Pit-1 Expression Plasmid

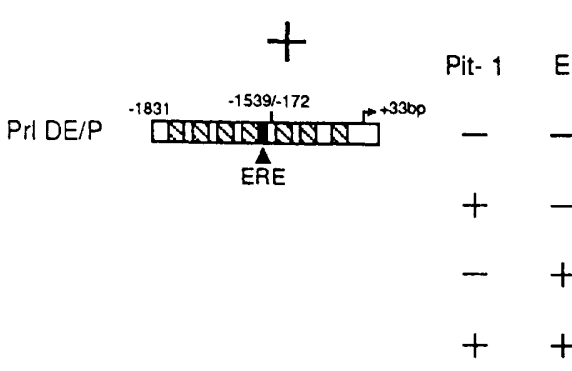

CV-1 Cells

(Fold-Stimulation Above Baseline)

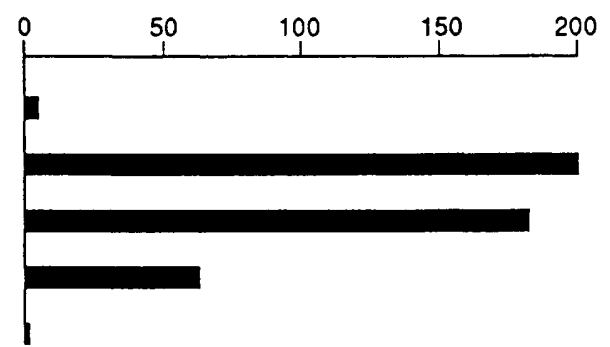

\section{OR}

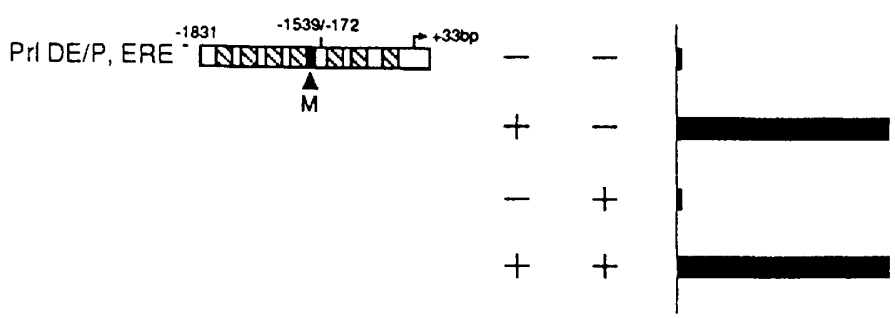

Figure 6. (See facing page for legend.) 
Pit-1, estrogen receptor synergistic interaction. This could reflect the actions of the estrogen receptor alone or in concert with Pit-1 on the distal enhancer. Therefore, the estrogen receptor appears to represent at least one synergistic factor capable of producing a 10 - to 30 -fold increase in PRL gene expression that is observed after birth. It remains to be established whether this reflects interactions between estrogen receptor with Pit-1 elements in the proximal promoter or distal enhancer, or both.

\section{Discussion}

The results presented in this manuscript have provided several insights into the development of a complex mammalian organ, the adenohypophysis. While the anatomic details of the serial movement of somatic ectoderm prior to cellular proliferation and the subsequent development of Rathke's pouch is well documented (Chatelain et al. 1979; Watanabe and Daikoku 1979; Watanabe 1979; Oliver et al. 1980l, a cell-specific marker to establish the earliest appearance of the primordial pituitary cells during early developmental events has been lacking. Unexpectedly, expression of the gene encoding the $\alpha$-subunit of the glycoprotein hormones by early e11 in a broad band of cells in the somatic ectoderm, including those that are progenitors for the intermediate lobe, establishes these cells as the primordial pituitary cells in the somatic ectoderm, and provides a marker to investigate the molecular events responsible for progression to Rathke's pouch and mature pituitary cells. We find that thyrotrophs, corticotrophs, and gonadotrophs also exhibit distinct spatial patterns of hormone mRNA expression, while GH and PRL transcripts exhibit an apparent, although, much less defined, spatial pattern of appearance. Thyrotrophs and corticotrophs emerge on e13-e14 in distinct rostral and caudal parts of the expanding anterior lobe. It is intriguing that cells in which the POMC gene is expressed on el4 were, on e12, in direct apposition to cells expressing the POMC gene in the developing hypothalamus, provoking speculation about the potential role of specific regulatory molecules in triggering the appearance of specific pituitary phenotypes.
The expression of Pit-1 protein during embryogenesis precedes the initial appearance of PRL and GH transcripts, and is consistent with the reported ability of Pit-1 to trans-activate fusion genes under control of the PRL and GH promoters in heterologous cell types (Ingraham et al. 1988, 1990; Mangalam et al. 1989; Jong et al. 1989). The only failure to observe Pit-1-dependent coordinate regulation of GH and PRL promoters involved comparison of a human $\mathrm{GH}$ promoter with a rat PRL promoter truncated at -9 bp (Castrillo et al. 1989).

Lactotrophs appear to arise from a somatotroph or presomatotroph cell (Behringer et al. 1988; Borelli et al. 1989); thus, secondary mechanisms must subsequently restrict GH gene expression out of lactotrophs, and concurrently enhance PRL expression to the physiological levels characteristic of mature lactotrophs. The very existence of a significant percentage of cells expressing GH and PRL (somatomammotrophs) in the mature gland (Hoeffler et al. 1985) itself argues that complete restriction of either gene product might, in part, reflect limitations in the assays used. It is quite possible that many, or even most, somatotrophs and lactotrophs express limited amounts of PRL and GH, respectively, which are below current levels of detection. Analyses of PRL fusion genes in cultured cells (Nelson et al. 1988) and in transgenic animals (Crenshaw et al. 1989) suggest that synergistic interactions between the PRL proximal promoter and distal enhancer are critical for physiological levels of PRL gene expression. Because an estrogen response element is located in the distal enhancer, and because the plasma estrogen and pituitary estrogen receptor levels have been reported to increase in concert with increasing PRL gene expression /Slabaugh et al. 1982), the estrogen receptor was evaluated as a candidate for a factor that, in synergy with Pit-1, might account for the ontogeny of PRL expression. Based on observed synergistic transcriptional effects consequent to binding to a response element in the distal enhancer, the estrogen receptor is suggested to be capable of acting, with Pit-1, to, in part, produce the characteristic large postnatal increase in PRL gene expression.

Conversely, we would suggest that additional mechanisms serve to restrict expression of growth hormone out of both lactotrophs and thyrotrophs, and PRL out of

Figure 6. Combinatorial actions of at least two factors are required for the characteristic activation of the PRL distal enhancer. $(A)$ Transcription of rat PRL and rat GH fusion genes in GC pituitary cells. Fusion genes under control of the PRL promoter ( 176 to +33 ) (Prl P), distal enhancer ( -1831 to -1553 fused to a -36 to +33 PRL promoter) (Prl DE), or a construction containing both distal enhancer and promoter $(\operatorname{Prl} \mathrm{DE} / \mathrm{P})$ were compared with expression of the fusion genes under control of the GH promoter $(\mathrm{GH}-310)$ or $\mathrm{T}_{3}$ response element (TRE). Results are the average of triplicate determinations differing by $<5 \%$; similar results were obtained in four experiments of similar design. $(B)$ Expression of rat PRL and rat GH fusion genes in Pit- $1^{ \pm}$HeLa cells that express Pit-1 at levels $<10$-fold those in GC cells, as documented by Western blot analysis. Comparable results were observed in five independent experiments. $(C)$ Cooperative interactions of Pit- 1 and estrogen receptor on distal enhancer function. Expression plasmids encoding human estrogen receptor or rat Pit-1 under control of the CMV promoter (Ingraham et al. 1988) were cotransfected with transcription units under the control of the indicated PRL promoter/distal enhancer. Background was determined by utilizing a CMV expression plasmid harboring a control insert (see Experimental methods) and subtracted from the results of the Pit-l expression plasmid. The estrogen response element in the distal enhancer was changed to a nonbinding site by a 6-bp cluster mutation (M), as previously described (Adler et al. 1988). Where indicated, estradiol- $17 \beta\left(10^{-8} \mathrm{M}\right)$ was added for $24 \mathrm{hr}$ prior to harvest. Media conditions were as previously described (Adler et al. 1988). Results are the average of duplicate determinations differing by $<5 \%$. Similar results are obtained in three experiments of similar design. 
Simmons et al.

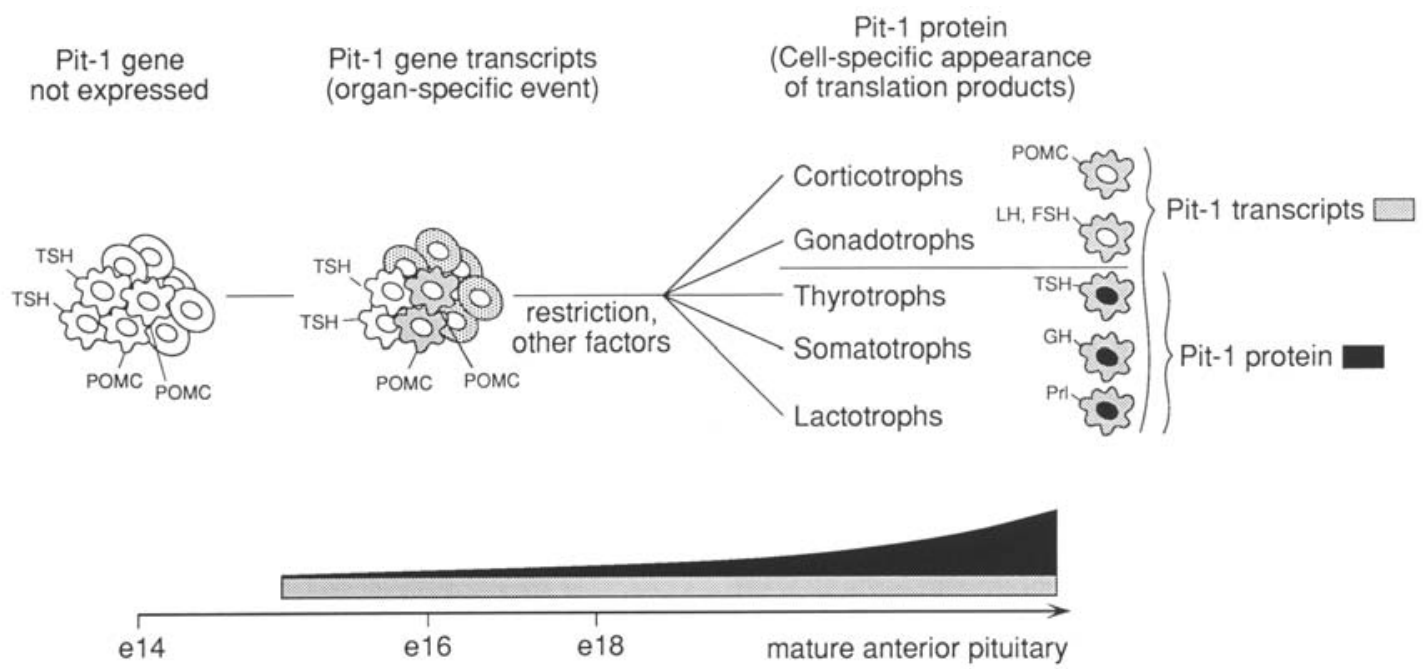

Figure 7. Combinatorial determination of ontogeny of cell phenotypes in the anterior pituitary gland. The initial appearance of each cell type based on detectable expression of trophic hormone transcripts is represented schematically. The temporal pattern of appearance of Pit-1 transcript and protein are indicated, with Pit-1 protein detected only in somatotrophs, lactotrophs, and thyrotrophs. The required actions of additional activating and restricting factors are indicated. Estrogen receptors which dramatically increase after birth, are postulated to represent one of the critical factors for activating the function of the distal enhancer of the rat PRL gene, by direct or indirect synergistic interactions with Pit-1. Synergism between the PRL distal enhancer and promoter are required for a physiological level of expression of the PRL gene (Crenshaw et al. 1989), characteristic of the mature lactotroph.

thyrotrophs and somatotrophs. Consistent with this interpretation, a distinct genomic region has been sug. gested to be required to restrict PRL gene expression out of thyrotrophs (Crenshaw et al. 1989), and a similar suggestion has been made for the GH gene (Lira et al. 1988). The failure of $\mathrm{GH}$ to be expressed in detectable levels in thyrotrophs or in lactotrophs also implies a multifactorial basis for GH gene expression, and this appears to involve the actions of both restrictive and activating factors. Indeed, based on analyses of transgenic mice, elements $5^{\prime}$ to the two Pit-1 sites serve to increase rat GH gene expression $>20$-fold (Lira et al. 1988). In concert, these observations formally eliminate models proposing that all cells expressing Pit-1 (GHF-1) would selectively and obligatorily express the GH gene (Castrillo et al. 1989). The apparent multifactorial activation of pituitary hormone gene expression is entirely in concert with the overlapping pattern of developmental activators that physiologically activate and restrict gene expression in much simpler organisms such as yeast, $C$. elegans, and Drosophila (Ptashne 1986; Gehring 1987; Scott and Carroll 1987; Herskowitz 1989).

An unexpected finding was that Pit-1 mRNA continues to be highly expressed in all five mature pituitary cell types, while protein is detectable only in somatotrophs, lactotrophs, and thyrotrophs (Fig. 7). The absence of detectable Pit-1 protein in about $20 \%$ of somatotrophs, lactrotrophs, and thyrotrophs is likely to reflect variation in levels of expression; however, the existence of a distinct subpopulation for all three cell types is a formal possibility. The specific hybridization of 3 '-untranslated probes of the Pit-1 mRNA, the failure to detect any alternatively spliced species by RNase protection assays, and the apparent use of the identical CAP site in GC and total pituitary transcripts were all consistent with the interpretation that Pit-1 mRNA was expressed in all five cell types. The most probable explanation for these findings is that a specific inhibitory mechanism prevents translation of Pit-l mRNA in gonadotrophs and corticotrophs. There are few examples in which mRNA-specific translational control has been suggested to operate as a developmental strategy (MacDonald and Struhl 1986; Vassalli et al. 1989|. The caudal gene in Drosophila appears to exhibit a gradient of protein expression; however, reactive transcripts are reported to be evenly distributed across the embryo (Levine 1985; Mlodzik et al. 1985; MacDonald and Struhl 1986). Bicoid mutants abolish the gradient of protein expression, confirming the authenticity of reactive transcripts (MacDonald and Struhl 1986). It is intriguing that bicoid, a homeo domain protein, also contains a consensus RNA-binding motif, suggesting the possibility that it binds directly to caudal transcripts (Rebagliati 1989). Of course, differential protein stability, rather than mRNA translation, could formally account for the observations in the case of both caudal and Pit-1 selective protein expression. For other genes, altered CAP site usage leads to an mRNA exhibiting altered translation (Gawl et al. 1989). In one well-studied example of posttranscriptional regulation in the differentiated cell, it has been suggested that a putative iron-binding factor can bind to two transcripts, ferritin and transferrin, resulting in control of translation and mRNA degradation, respectively (Leibold and Munro 1988; Mullner et al. 1989; Rouault et al. 1989).

The intriguing implications of the data are that Pit-1 gene activation represents an organ-specific event; however, the protein products of the Pit-1 transcripts are not 
detected in all mature cell types, possibly on the basis of translational control. These data would suggest that a distinct cell-specific mechanism might be responsible for the translational "block" in gonadotrophs and corticotrophs. The actions of Pit-1 protein are complemented by other interacting factors that are required to achieve the physiological patterns of gene activation. In the case of the developing lactotroph, the appearance of estrogen receptor subsequent to Pit-1 expression initiates synergistic interactions that could produce progressive increase in PRL gene expression to levels characteristic of those in mature lactotrophs by permitting functional activation of the distal enhancer. The combinatorial interactions between transcriptional regulators containing POU-domain and zinc-coordinated finger DNA-binding motifs that, in part, account for the ontogenic patterns of quantitative PRL gene expression, are likely to be prototypic for similar events in development of other mammalian organs. Clearly, other mechanisms must operate to restrict PRL and GH gene expression correctly from thyrotrophs and from somatotrophs and lactotrophs, respectively.

\section{Experimental methods}

\section{Tissue preparation}

Timed-pregnant Sprague-Dawley rats were purchased from Zivic-Miller (Zelienople, Pennsylvania); time of insemination (confirmed later by vaginal plug) was around midnight and was considered the beginning of embryonic day $0(\mathrm{e} 0)$; animals were perfused around noon (EDT) an appropriate number of days later. For this, the animals were deeply anesthetized with chloral hydrate, and perfused transcardially with saline, followed by $4 \%$ paraformaldehyde at $\mathrm{pH} 6.5$ and then $4 \%$ paraformaldehyde at $\mathrm{pH} 9.5$, as described previously (Simmons et al. 1989). The embryos were then removed and postfixed overnight at $4^{\circ} \mathrm{C}$ in paraformaldehyde ( $\mathrm{pH} 9.5$ ) with $10 \%$ sucrose. Serial $10-\mu \mathrm{m}$-thick sagittal or frontal sections through the embryos were cut in a cryostat, and mounted on subbed, poly-L-lysinecoated slides (Simmons et al. 1989). For Pit-1 immunohistochemistry, the fixative consisted only of $4 \%$ paraformaldehyde at $\mathrm{pH} 9.5$, and the tissue was also postfixed overnight as above. Alternatively, pituitary glands (or neural regions) were collected under the dissection microscope and frozen from unperfused animals; pituitaries from two litters were pooled and processed. To characterize the ontogenetic appearance of transcripts in the pituitary, animals on each day from e10 through postnatal day $2(\mathrm{p} 2)$ were examined with each of the probes listed below; four to six embryos were examined for each probe on the days just before and after initial expression; one to three embryos were examined at the other ages.

Cultures of dispersed rat anterior pituitary cells were prepared as described elsewhere (Vale et al. 1983) and $5 \times 10^{5}$ cells were plated onto LabTek two-well culture slides. They were fixed by immersion with $4 \%$ paraformaldehyde ( $\mathrm{pH} 9.5$ at $4^{\circ} \mathrm{C}$ ) for $15 \mathrm{~min}$.

\section{Histochemistry}

In situ hybridization on embryo sections was carried out as described in detail elsewhere (Simmons et al. 1989), except that $0.05 \%$ Triton X-100 at room temperature was used instead of proteinase $\mathrm{K}$, and the acetic anhydride step was omitted in the hybridization pretreatment. Immunohistochemistry on both tissue sections and cultured cells was carried out using the same methods. In brief, tissue was pretreated for $30 \mathrm{~min}$ with $\mathrm{KPBS}+$ [potassium phosphate-buffered saline (KPBS, pH 7.4) containing $2 \%$ normal goat serum and $0.3 \%$ Triton X-100]; after rinsing $2 \times 10 \mathrm{~min}$ in KPBS. Primary antibodies were diluted in KPBS with $0.02 \%$ sodium azide and applied for 24-72 $\mathrm{hr}$ at $4^{\circ} \mathrm{C}$. Tissue was then rinsed $2 \times 10 \mathrm{~min}$ with KPBS at room temperature, and secondary antibodies diluted in KPBS + were applied for $60 \mathrm{~min}$ at room temperature. All histochemical material (except combined immunohistochemistry/in situ hybridization) was counterstained with bisbenzimide to show cellular details (Schmued et al. 1982). The method used for combining immunohistochemistry with in situ hybridization has been described elsewhere (Watts and Swanson 1989).

\section{${ }^{35} S / R N A$ probes and antibodies}

$\left[{ }^{35} \mathrm{~S}\right] \mathrm{cRNA}$ probes were transcribed from linearized DNA templates using Riboprobe Gemini kits purchased from Promega Biotech, Madison, WI $)$ and ${ }^{35}$ S $]$ UTP $(1,000-1,500 \mathrm{Ci} / \mathrm{mM}$; New England Nuclear, Boston, MA) as described elsewhere (Simmons et al. 1989). The following cDNA inserts in either SP64 or pGem vectors were used: mouse $\alpha$-GSU (460-nucleotide fragment supplied by P.L. Mellon, The Salk Institute; see Chin et al. 1981), rat $\alpha$ GSU (495-nucleotide fragment, supplied by W.W. Chin, Harvard University; see Godine et al. 1982); mouse $\beta$ TSH (430-nucleotide fragment, supplied by P.L. Mellon, The Salk Institute; see Gurr et al. 1983); rat $\beta \mathrm{LH}$ (300nucleotide fragment, supplied by J.L. Roberts, Mt. Sinai School of Medicine; see Tepper and Roberts 1984); rat $\beta F S H$ (874-nucleotide fragment, supplied by P.L. Mellon; see Maurer 1987); rat GH (800-nucleotide fragment) and rat PRL (780-nucleotide fragment; see Gubbins et al. 1980), rat POMC (500-nucleotide fragment of exon 3 supplied by J.L. Roberts, Mt. Sinai School of Medicine; see Chen et al. 1983). Pit-1 RNA probes were synthesized from pBluescript SK-based vectors (Stratagene). Probes consisted of either a $0.37-\mathrm{kb}$ EcoRI fragment (A) from the coding region at the $5^{\prime}$ end of the cDNA, a $0.55-\mathrm{kb}$ EcoRI fragment from the internal part of the coding region that contains the homeo box (B), a 1.2-kb EcoRI fragment of the cDNA that contains only $3^{\prime}$-untranslated region (C) (Ingraham et al. 1988). Qualitative results were equivalent with all three probes, but the combination of all probes provides the greatest quantitative signal. All probes were used at a concentration of $10^{7} \mathrm{cpm} / \mathrm{ml}$. As a control for hybridization specificity, sense-strand control probes were synthesized; none showed labeling of cells in the pituitary.

The following antibodies were used for immunohistochemistry; sheep anti-rat ACTH polyclonal (D.N. Orth, Vanderbilt University; $1: 2000$ ); rabbit anti-human ACTH polyclonal (ucb Bioproducts; $1: 1000$ ); mouse anti-human $\beta$ TSH monoclonal \{ucb Bioproducts; $1: 5000$ ); rabbit anti-human $\beta$ TSH polyclonal (BioGenex; $1: 5000)$; mouse anti-human $\beta$ LH monoclonal (BioGenex; $1: 2000$ ); and rabbit anti-human $\beta$ LH polyclonal (Cambridge Medical Diagnostics; $1: 2000 \mid$.; mouse anti-human $\beta F S H$ monoclonal (Ventrex; $1: 10,000$ ); rabbit anti-human $\beta F S H$ polyclonal (Cambridge Medical Diagnostics; 1:2000); monkey anti-mouse GH polyclonal (W. Van der Laan, Whittier Institute; $1: 20,000$ ); rabbit anti-ovine $\mathrm{GH}$ polyclonal (Immunonuclear Corporation; $1: 2000)$; and rabbit anti-human PRL polyclonal (ucb Bioproducts; 1:2000). Specific staining was blocked by absorption to the homologous antigen $11 \mathrm{mg}$ antigen to $1 \mathrm{ml}$ of antibody diluted $1: 200$; absorbed overnight at $4^{\circ} \mathrm{C}$, then diluted to appropriate staining concentration).

Secondary antisera used to detect these antibodies included: 
goat anti-rabbit IgG conjugated to fluorescein or rhodamine (Tago; $1: 200$ ); biotinylated goat anti-rabbit IgG (Vector Laboratories; $1: 200$ ); goat anti-sheep IgG conjugated to fluorescein (Litton Bionetics; $1: 50$ ); goat anti-mouse IgG conjugated to fluorescein or rhodamine (American Qualex; $1: 100$ ); and goat anti-human IgG conjugated to rhodamine (Cappel; $1: 200$ ).

\section{RNase protection and primer extension assays}

Poly(A)-selected RNA isolated from GC cells, or pituitary, estrogen-treated pituitary, as described previously (Ingraham et al. 1988), was subjected to RNase protection analysis as described (He et al. 1989). Briefly, a clone that contained Pit-1 cDNA extending $3^{\prime}$ to a portion of the POU domain in pBKS (Stratagene) was used to generate labeled antisense probe, using T7 RNA polymerase (Studier and Moffat 1986) in the presence of $\left[{ }^{32} \mathrm{P}\right] \mathrm{UTP}(>800 \mathrm{Ci} / \mathrm{mmole})$, that generated an RNA transcript of 538 nucleotides. As we have previously described $(\mathrm{He}$ et al. 1989); 355 nucleotides were contributed by Pit-1 cDNA. RNA $(20 \mu \mathrm{g})$ was hybridized to $5 \times 10^{5} \mathrm{cpm}$ antisense probe (heated to $85^{\circ} \mathrm{C}$ and annealed for $12 \mathrm{hr}$ at $45^{\circ} \mathrm{C}$ ) and digested with RNase $\mathrm{A}(30 \mu \mathrm{g} / \mathrm{ml})$ at $30^{\circ} \mathrm{C}$ for $45 \mathrm{~min}$ prior to electrophoresis on a sequencing gel. Markers used were the BRL $1-\mathrm{kb}$ standard ladder. mRNA transcription initiation site analysis was performed with total RNA isolation from pituitary glands from adult rats, retired breeders treated for 10 days with estrogen, or GC cells, as previously described (Elsholtz et al. 1986) using a 30-bp antisense primer that would generate a 320 -nucleotide fragment, based on the characterization of the Pit-1 gene (R. Chen, H.A. Ingraham, M.N. Treacy, V.R. Albert, and M.G. Rosenfeld, in prep.), labeled to $10^{9} \mathrm{cpm} / \mathrm{mg}$. Primer extension products were analyzed on $8 \%$ polyacrylamide gels.

\section{Cotransfection analyses}

Reporter plasmid vectors containing either rat PRL 5 '-flanking information $(-1831$ to $-1530 /-178$ to +36$)$, rat GH information $(-320$ to +8$)$, and the firefly luciferase gene (de Wet et al. 1987) were prepared as previously described (Nelson et al. 1988). Expression plasmids for Pit-1 or a control plasmid containing a noncoding portion of the epidermal growth factor receptor $(\mathrm{Ct})$ were under transcriptional regulation of the CMV promoter region, as previously described (Ingraham et al. 1990). An SV40 splice poly(A) site was 3' of the inserted DNA. CV-1, GC, or Pit $-1^{ \pm}$HeLa cells were transfected with each reporter plasmid $(10 \mu \mathrm{g})$ using the calcium phosphate coprecipitation procedure (Chen and Okayama 1987) and $10 \mu \mathrm{g}$ of the expression vector containing the Pit-1 insert or $\mathrm{Ct}$ insert. Luciferase assays were performed as previously described (de Wet et al. 1987) $48 \mathrm{hr}$ following transfection. Permanently transfected Pit- ${ }^{ \pm}$HeLa cells used were previously described (Mangalam et al. 1989).

\section{Preparation of antisera directed against Pit-1}

Approximately $100 \mu \mathrm{g}$ of Pit-1 protein purified by phosphocellulose chromatography of protein extracts produced from an $E$. coli expression system (Mangalam et al. 1989) was used to immunize a 3-lb female New Zealand white rabbit, which was subsequently boosted twice with similar preparations of protein.

\section{Preparation of embryonic cell protein extracts}

Pituitary glands were harvested from pregnant rats at the indicated times after fertilization by microsurgery and pooled. The pooled pituitaries were sonicated in $10 \mathrm{mM} \mathrm{KCl}, 20 \mathrm{mM}$ HEPES (pH 7.8), $1 \mathrm{~mm} \mathrm{MgCl}_{2}$, and $0.1 \% \mathrm{NP}-40$. After sonication, the lysates were adjusted to $300 \mathrm{~mm}$ in $\mathrm{NaCl}$ and incubated on ice for $30 \mathrm{~min}$. Final soluble protein concentrations in lysates ranged from 2 to $7 \mathrm{mg} / \mathrm{ml}$. A $0.5-\mu \mathrm{g}$ amount of total pituitary protein was used for gel mobility-shift analysis and $30 \mu \mathrm{g}$ of total pituitary protein was used in Western blot analysis. Western transfers were made using a Novablot apparatus (Pharmacia/LKB) following the manufacturer's recommendations. Final antiserum dilutions for both Western blot and gel-shift analysis were $1: 1000$. Pit- 1 reactive species were visualized using a horseradish peroxidase colorimetric assay and a biotin/ avidin amplification system (Vector Labs).

\section{Acknowledgments}

We particularly acknowledge the experimental contributions of Maurice Treacy, Vivian Albert, Bryan Crenshaw, Charles Nelson, and Stuart Adler, as well as the suggestions of Christopher Glass, Xi He, and Ron Emeson. We thank Susan Inglis for the preparation of this manuscript. This work was supported by grants from the NIAMDD. M.G.R. and L.W.S. are Investigators of the HHMI. J.H. is a postdoctoral fellow in the Department of Chemistry, UCSD.

\section{References}

Adelmann, H.B. 1925. The development of the neural folds and cranial ganglia of the rat. J. Comp. Neur. 39: 19-171.

Adler, S., M.L. Waterman, H. Xi, and M.G. Rosenfeld. 1988. Steroid receptor-mediated inhibition of rat prolactin gene expression does not require the receptor DNA-binding domain. Cell 52: 685-695.

Beato, M. 1989. Gene regulation by steroid hormones. Cell 56: 335-344.

Begeot, M., M.P. Dubois, and P. Dubois. 1982. Comparative studies in vivo and in vitro of the differentiation of immunoreactive corticotropic cells in fetal rat anterior pituitary. Neuroendocrinology 35: 255-264.

Behringer, R.R., L.S. Mathews, R.D. Palmiter, and R.L. Brinster. 1988. Dwarf mice produced by genetic ablation of growth hormone-expressing cells. Genes Dev. 2: 453-461.

Bodner, M. and M. Karin. 1987. A pituitary-specific trans-acting factor can stimulate transcription from the growth hormone promoter in extracts of nonexpressing cells. Cell 50:267275.

Bodner, M., J.-L. Castrillo, L.E. Theill, T. Deerinck, M. Ellisman, and M. Karin. 1988. The pituitary-specific transcription factor GHF-l is a homeobox-containing protein. Cell 55: 505-518.

Borrelli, H.R., C. Arias, P.E. Sawchenko, and R. Evans. 1989. Transgenic mice with inducible dwarfism. Nature 339: $538-541$.

Cao, Z., E.A. Barron, A.J. Carrillo, and Z.D. Shapr. 1987. Reconstitution of cell-type-specific transcription of the rat prolactin gene in vitro. Mol. Cell. Biol. 7: 3402-3408.

Castrillo, J.-L., M. Bodner, and M. Karin. 1989. Purification of growth hormone-specific transcription factor GHF-1 containing homeobox. Science 243: 814-817.

Chatelain, A., J.P. Dupuoy, and M.P. Dubois. 1979. Ontogenesis of cells producing polypeptide hormones $1 \mathrm{ACTH}$ MSH, LPH, GH, Prolactin) in the fetal hypophysis of the rat: Influence of the hypothalamus. Cell Tissue Res. 196: 409427.

Chen, C. and H. Okayama. 1987. High efficiency transforma- 
tion of mammalian cells by plasmid DNA. Mol. Cell. Biol. 7: 2745-2752.

Chen, C.L., F.T. Dionne, and J.L. Roberts. 1983. Regulation of pro-opiomelanocortin mRNA levels in rat pituitary by dopaminergic compounds. Proc. Natl. Acad. Sci. 80: 2211-2215.

Childs, G.V., K.N. Vestlund, and G. Unabia. 1989. Characterization of anterior pituitary target cells for arginine vasopressin: including cells that stain adrenocorticotrophin, thyrotrophin, and both hormones. Endocrinology 124: 554559.

Chin, W.W., H.M. Kronenberg, P.C. Dee, F. Maloof, and J.F. Habener. 1981. Nucleotide sequence of the mRNA encoding the pre- $\alpha$-subunit of mouse thyrotropin. Proc. Natl. Acad. Sci. 78: 5329-5333.

Clerc, R.G., L.M. Corcoran, J.H. LeBowitz, D. Baltimore, and P.A. Sharp. 1988. The B-cell-specific Oct-2 protein contains POU box- and homeo box-type domains. Genes Dev. 2: $1570-1581$.

Costa, R.H., D.R. Grayson, K.G. Xanthopoulos, and J.D. Darnell. 1988. A liver-specific DNA binding protein recognizes multiple nucleotide sites in regulatory regions of transthyretin, $\alpha 1$-antitrypsin, albumin, and simian virus 40 serum. Proc. Natl. Acad. Sci. 85: 3840-3844.

Couly, G.F. and N.M. LeDouarin. 1985. Mapping of the early neural primordium in quail-chick chimeras. Dev. Biol. 110: $422-439$.

Courtois, G., J.G. Morgan, L.A. Campbell, G. Fourel, and G.R. Crabtree. 1987. Interaction of a liver-specific nuclear factor with the fibrinogen and $\alpha 1$-antitrypsin promoters. Science 238: $688-692$.

Crenshaw III, E.B., K. Kalla, H.A. Ingraham, D.M. Simmons, L.W. Swanson, and M.G. Rosenfeld. 1989. Cell-specific expression of the prolactin gene in transgenic mice is controlled by synergistic interactions between Pit-1 recognition elements. Genes Dev. 3: 959-972.

Daikoku, S., H. Kawano, K. Abe, and K. Yoshinaga. 1981. Topographical appearance of adenohypophysial cells with special reference to the development of the portal system. Arch. Histol. Jap. 44: 103-116.

Daikoku, S., M. Chikamori, and Y. Maki. 1982. Effect of the basal diencephalon on the development of Rathke's pouch in rats: A study in combined organ cultures. Dev. Biol. 90: 197-202.

Daikoku, S., M. Chikamori, T. Adachi, Y. Okamura, T. Nishiyama, and Y. Tsuruo. 1983. Ontogenesis of hypothalamic immunoreactive ACTH cells in vivo and in vitro: Role of Rathke's pouch. Dev. Biol, 97: 81-88.

Dearden, N.M. and R.L. Holmles. 1976. Cyto-differentiation and portal vascular development in the mouse adenohypophysis. J. Anat. 121: 551-569.

de Wet, J.R., K.V. Wodd, M. Deluca, D.R. Helinski, and S. Subramani. 1987. Firefly luciferase gene: structure and expression in mammalian cells. Mol. Cell. Biol. 7: 725-737.

Elsholtz, H.P., H.J. Mangalam, E. Potter, V.R. Albert, S. Supowit, R.M. Evans, and M.G. Rosenfeld. 1986. Two different cis-active elements transfer the transcriptional effcts of both EGF and phorbol esters. Science 234: 1552-1557.

Evans, R.M. 1988. Steroid and thyroid hormone receptors as transcriptional regulators of development and physiology. Science 240: 889-895.

Fink, G. and G.C. Smith. 1971. Ultrastructural features of the developing hypothalamo-hypophysial axis in the rat. $Z$. Zellforsch 119: 208-226.

Finney, M., G. Ruvkun, and H.R. Horvitz. 1988. The C. elegans cell lineage and differentiation gene unc- 86 encodes a protein containing a homeodomain and extended sequence sim- ilarity to mammalian transcription factors. Cell 55: 757 769.

Fox, S.R., M.T.C. Jong, J. Casanova, S.F. Ye, F. Stanley, and H.H. Samuels. 1990. The homeodomain protein, Pit-1/ GHF1, is capable of binding to and activating cell-specific elements of both the growth hormone and prolactin gene promoters. Mol. Endocrinol. (in press).

Frémont, P.H. and R. Ferrand. 1979. In vitro studies on the selfdetermination capacities of quail adenotrypophysis epithelium. Anat. Embryol. 156: 255-267.

Gash, D., N. Ahmad, and J. Schechter. 1982. Comparison of gonadotroph, thyrotroph and mammotroph development in situ, in transplants and in organ culture. Neuroendocrinology 34: 222-228.

Gawl, U., E. Seifert, R. Schuh, and H. Jäckle. 1989. Analysis of Krüppel protein distribution during early Drosophila development reveals post transcriptional regulation. Cell 50: $639-647$.

Gehring, W.J. 1987. Homeoboxes in the study of development. Science 236: 1245-1252.

Glass, C.K., J.M. Holloway, O.V. Devary, and M.G. Rosenfeld. 1988. The thyroid hormone receptor binds with opposite transcriptional effects to a common sequence motif in thyroid hormone and estrogen response elements. Cell 54: 313-323.

Glass, C.K., S.M. Lipkin, O.V. Devary, and M.G. Rosenfeld. 1989. Positive and negative regulation of gene transcription by a retinoic acid/thyroid hormone receptor heterodimer. Cell 59: 697-708.

Godine, J.E., W.W. Chin, and J.F. Habener. 1982. $\alpha$ Subunit of rat pituitary glycoprotein hormones. I. Biol. Chem. 257: 8368-8371.

Gubbins, E.J., R.A. Maurer, M. Lagrimini, R. Erwin, and J.E. Donelson. 1980. Structure of the rat prolactin gene. J. Biol. Chem. 255: 8655-8662.

Gurr, J.A., J.F. Catterall, and I.A. Kourides. 1983. Cloning of cDNA encoding the pre- $\beta$-subunit of mouse thyrotropin. Proc. Natl. Acad. Sci. 80: 2122-2126.

Gutierrez-Hartman, A., S. Siddiqui, and S. Loukin. 1987. Selective transcription and DNase I protection of the rat prolactin gene by $\mathrm{GH}_{3}$ pituitary cell-free extracts. Proc. Natl. Acad. Sci. 84: 5211-5215.

Hammer, R.E., G.H. Swift, D.M. Ornitz, C.J. Quaife, R.D. Palmiter, R.L. Brinster, and R.J. MacDonald. 1987a. The rat elastase 1 regulatory element is an enhancer that directs correct cell specificity and developmental onset of expression in transgenic mice. Mol. Cell. Biol. 7: 2956-2967.

Hammer, R.E., R. Krumlauf, S.A. Camper, R.L. Brinster, and S.M. Tilghman. 1987b. Diversity of $\alpha$-fetoprotein gene expression in mice is generated by a combination of separate enhancer elements. Science 235: 53-58

He, X., M.N. Treacy, D.M. Simmons, H.A. Ingraham, L.W. Swanson, and M.G. Rosenfeld. 1989. Expression of a large family of POU-domain regulatory genes in mammalian brain development. Nature 340: 35-42.

Herr, W., R.A. Sturm, R.G. Clerc, L.M. Corcoran, D. Baltimore, P.A. Sharp, H.A. Ingraham, M.G. Rosenfeld, M. Finney, G. Ruvkin, and H.R. Horvitz. 1988. The POU domain: A large conserved region in the mammalian Pit-1, Oct-1, Oct-2, and Caenorhabditis elegans unc-86 gene products. Genes Dev. 2: $1513-1516$.

Herskowitz, I. 1987. Functional inactivation of genes by dominant negative mutations. Nature 329: 219-222.

Hoeffler, J.P., F.R. Boockfor, and L.L. Frawley. 1985. Ontogeny of prolactin cells in neonatal rats: Initial prolactin secretors also release growth hormone. Endocrinology 117: 187-195. 
Ingraham, H.A., R. Chen, H.J. Mangalam, H.P. Elsholtz, S.E. Flynn, C.R. Lin, D.M. Simmons, L. Swanson, and M.G. Rosenfeld. 1988. A tissue-specific transcription factor containing a homeodomain specifies a pituitary phenotype. Cell 55: 519-529.

Ingraham, H.A., S.E. Flynn, J.W. Voss, V.R. Albert, M.S. Kapiloff, L. Wilson, and M.G. Rosenfeld. 1990. The POU specific domain of Pit-1 is essential for high affinity DNA binding sequence specificity and contributes to Pit-1-Pit-1 interactions. Cell (in press).

Jacobson, A.G. and A.K. Sater. 1988. Features of embryonic induction. Development 104: 341-359.

Kachaturian, H., N.E. Alessi, N. Munfakh, and S.J. Watson. 1983. Ontogeny of opioid and related peptides in the rat CNS and pituitary: An immunocytochemical study. Life Sci. 33: 61-64.

Ko, H-S., P. Fast, W. McBride, and L.M. Staudt. 1988. A human protein specific for the immunoglobulin octamer DNA motif contains a functional homeobox domain. Cell 55: 135-144.

Larkin, S., S. Tait, M.N. Treacy, and F. Martin. 1990. Characterization of tissue specific transacting factor binding to a proximal element in the rat growth hormone gene promoter. Eur. J. Chem. (in press).

Leibold, E.A. and H.N. Munro. 1988. Cytoplasmic protein binds in vitro to a highly conserved sequence in the $5^{\prime}$ untranslated region of ferritin heavy- and light-subunit. Proc. Natl. Acad. Sci. 85: 2171-2175.

Levine, M., G.M. Rubin, and R. Tjian. 1984. Human DNA sequences homologous to a protein coding region conserved between homeotic genes of Drosophila. Cell 38: 667-673.

Lira, S.A., E.B. Crenshaw III, C.K. Glass, L.W. Swanson, and M.G. Rosenfeld. 1988. Identification of rat growth hormone genomic sequences targeting pituitary expression in transgenic mice. Proc. Natl. Acad. Sci. 85: 4755-4759.

Lufkin, T. and C. Bancroft. 1987. Identification of cell fusion of gene sequences that interact with positive trans-acting factors. Science 237: 283-286.

Lugo, D.I., J.L. Roberts, and J.E. Pintar. 1989. Analysis of proopiomelanocortin gene expression during prenatal development of the rat pituitary gland. Mol. Endocrinol. 3: 13131324.

Macdonald, P.M. and G. Struhl. 1986. A molecular gradient in early Drosophila embryos and its role in specifying the body plan. Nature 324: 537-545.

Mangalam, H.J., V.R. Albert, H.A. Ingraham, M. Kapiloff, L. Wilson, C. Nelson, H. Elsholtz, and M.G. Rosenfeld. 1989. A pituitary POU domain protein, Pit-1, activates both growth hormone and prolactin promoters transcriptionally. Genes Dev. 3: 946-958.

Maurer, R.A. 1987. Molecular cloning and nucleotide sequence analysis of complementary deoxyribonucleic acid for the $\beta$ subunit of rat follicle stimulating hormone. Mol. Endocrinol. 1: 717-723.

Maurer, R.A. and A.C. Notides. 1987. Identification of an estrogen-response element from the $5^{\prime}$ flanking region of the rat prolactin gene. Mol. Cell. Biol. 7: 4247-4254.

Mlodzik, M., A. Fjose, and W.J. Gehring. 1985. Isolation of caudal, a Drosophila homeo box-containing gene with maternal expression, whose transcripts form a concentration gradient at the pre-blastoderm stage. EMBO I. 4: 29612969.

Müller, M., S. Ruppert, W. Schaffner, and P. Mathias. 1988. A cloned octomer transcription factor stimulates transcription from lymphoid-specific promoters in non-B cells. Nature 336: $544-551$.
Mullner, E.W., B. Neupert, and L.C. Kühn. 1989. A specific mRNA binding factor regulates the iron-dependent stability of cytoplasmic transferrin receptor mRNA. Cell 58: 373382.

Nelson, C., E.B. Crenshaw III, R. Franco, S.A. Lira, V.R. Albert, R.M. Evans, and M.G. Rosenfeld. 1986. Discrete cis-active genomic sequences dictate the pituitary cell type-specific expression in rat prolactin and growth hormone genes. $\mathrm{Na}$ ture 322: 557-562.

Nelson, C., V.R. Albert, H.P. Elsholtz, L.E.-W. Lu, and M.G. Rosenfeld. 1988. Activation of cell-specific expression of rat growth hormone and prolactin genes by a common transcription factor. Science 239: 1400-1405.

Oliver, C., R.L. Eskay, and J.C. Porter. 1980. Developmental changes in brain TRH and in plasma and pituitary TSH and prolactin levels in the rat. Biol. Neonarte. 37: 145-152.

Ptashne, M. 1986. The genetic switch. Cell and Blackwell Scientific Publications. pp. 1-140.

Rebagliati, M. 1989. An RNA recognition motif in the bicoid protein. Cell 58: 231-232.

Rouault, T.A., M.W. Hentze, D.J. Haile, J.B. Harford, and R.D. Klausner. 1989. The iron-responsive element binding protein: a method for the affinity purification of a regulatory RNA-binding protein. Proc. Natl. Acad. Sci. 86: 5768-5772.

Schechter, J., D. Gash, and N. Ahmad. 1985. Mesenchymal influences on the development of the adenohypophysis in the rat. Cell Tissue Res. 241: 67-76.

Scheidereit, C., J.A. Cromlish, T. Gerster, K. Kawakami, C.-G. Balmaceda, R.A. Currie, and R.G. Roeder. 1988. A human lymphoid-specific transcription factor that activates immunoglobulin genes in a homeobox protein. Nature 336: $552-$ 557.

Schmued, L.C., L.W. Swanson, and P.E. Sawchenko. 1982. Some fluorescent counterstains for neuroanatomical studies. I. Histochem. Cytochem. 30: 123-128.

Schwartzberg, D.G. and P.K. Nakone. 1982. Ontogenesis of adrenocorticotropin-related peptide determinants in the hypothalamus and pituitary gland of the rat. Endocrinology 110: $855-860$.

Schwind, J. 1928. The development of the hypophysis cerebri of the albino rat. Am. J. Anat. 41: 295-319.

Scott, M.P. and S.B. Carroll. 1987. The segmentation and homeotic gene network in early Drosophila development. Cell 51: $689-698$.

Simmons, D.M., J.L. Arriza, and L.W. Swanson. 1989. Complete protocol for in situ hybridization in brain and other tissues with radiolabeled single-stranded RNA probes. I. Histotechnol. 12: 169-181.

Singh, H., J.H. LeBowitz, A.S. Baldwin, Jr., and P.A. Sharp. 1988. Molecular cloning of an enhancer binding protein: Isolation by screening of an expression library with a recognition site DNA. Cell 52: 415-429.

Slabaugh, M.D., M.E. Lieberman, J.J. Rutledge, and J. Gorski. 1982. Ontogeny of growth hormone and prolactin gene expression in mice. Endocrinology 110: 1489-1497.

Southern, E.M. 1975. Detection of specific sequences among DNA fragments separated by gel electrophoresis. I. Mol. Biol. 98: 503-517.

Staudt, L.M., H. Singh, R. Sen, T. Wirth, P.A. Sharp, and D. Baltimore. 1986. A lymphoid-specific protein binding to the octomer motif of immunoglobulin genes. Nature 323: 640643.

Sternberg, P.W. and H.P. Horvitz. 1984. The genetic control of cell lineage during nematode development. Annu. Rev. Genet. 18: 489-524.

Studier, F.W. and B.A. Moffat. 1986. Use of bacteriophage T7 
RNA polymerase to direct selective high-level expression of cloned genes. J. Mol. Biol. 189: 13-130.

Sturm, R.A., G. Das, and W. Herr. 1988. The ubiquitous octamer-binding protein Oct-1 contains a POU-domain with a homeo box subdomain. Genes Dev. 2: 1582-1599.

Tepper, M.A. and T.L. Roberts. 1984. Evidence for only one $\beta$ luteinizing hormone and no $\beta$-chorionic gonadotropin gene in the rat. Endocrinology 115: 385-391.

Vale, W., J. Vaughan, G. Yamamoto, T. Bruhn, C. Douglas, D. Dalton, C. Rivier, and J. Rivier. 1983. Assay of corticotropin releasing factor. Methods Enzymol. 103: 565-577.

Vassalli, J.D., J. Huarte, D. Belin, P. Gubler, A. Vassalli, M.L. O'Connell, L.A. Parton, R.J. Rickles, and S. Strickland. 1989. Regulated polyadenylation controls mRNA translation during meiotic maturation of mouse oocytes. Genes Dev. 3: $2163-2171$.

Walker, M., T. Edlund, A.M. Boulet, and W.J. Rutter. 1983. Cell-specific expression controlled by the $5^{\prime}$ flanking region of insulin and chymotrypsin genes. Nature 306: 557-561.

Watanabe, Y.G. 1982. Effects of brain and mesenchyme upon the cytogenesis of rat adenohypophresis in vitro. Cell Tissue Res. 227: 257-266.

Watanabe, Y.D. and S. Daikoku. 1979. An immunohistochemical study on the cytogenesis of adenohypophysial cells in fetal rats. Dev. Biol. 68: 559-567.

Waterman, M.L., S. Adler, C. Nelson, G.L. Greene, R.M. Evans, and M.G. Rosenfeld. 1987. A single domain of the estrogen receptor confers deoxyribonucleic acid binding and transcriptional activation of the rat prolactin gene. Mol. Endocrinol. 2: 14-21.

Watts, A.G. and L.W. Swanson. 1989. Combination of in situ hybridization with immunohistochemistry and retrograde tract-tracing. Meth. Neurosci. 1: 127-136.

West, B.L., D.F. Catanzaro, S.H. Mellon, P.A. Cattini, J.D. Baxter, and T.L. Reudelhuber. 1987. Interaction of a tissuespecific factor with an essential rat growth hormone gene promoter element. Mol. Cell. Biol. 7: 1193-1197.

Ye, Z.S. and H.H. Samuels. 1987. Cell- and sequence-specific binding of nuclear proteins to $5^{\prime}$-flanking DNA of the rat growth hormone gene. I. Biol. Chem. 262: 6313-6317. 


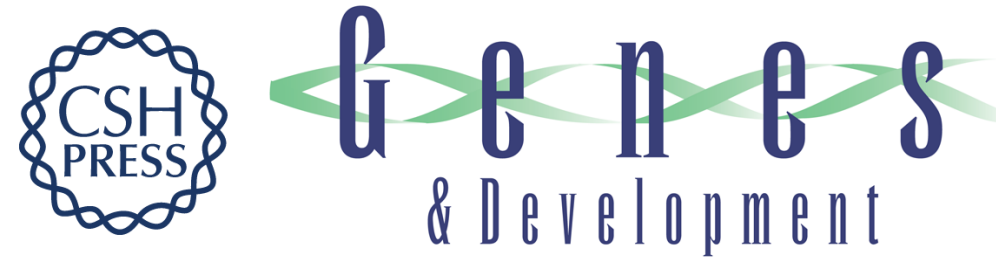

\section{Pituitary cell phenotypes involve cell-specific Pit-1 mRNA translation and synergistic interactions with other classes of transcription factors.}

D M Simmons, J W Voss, H A Ingraham, et al.

Genes Dev. 1990, 4:

Access the most recent version at doi:10.1101/gad.4.5.695

References This article cites 90 articles, 33 of which can be accessed free at: http://genesdev.cshlp.org/content/4/5/695.full.html\#ref-list-1

License

Email Alerting Service

Receive free email alerts when new articles cite this article - sign up in the box at the top right corner of the article or click here.

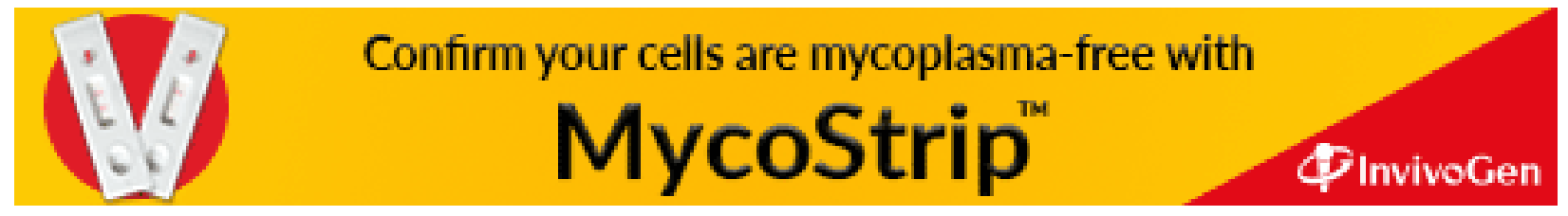

